\title{
PHYSIOLOGICAL RESPONSES OF DROUGHT STRESSED WHEAT PLANTS (Triticum aestivum L.) TREATING WITH SOME BACTERIAL ENDOPHYTES

\author{
El-Afry, M. M. ${ }^{\star *}$; M. F. El-Nady ${ }^{\star \star}$; E. B. A. Belal ${ }^{\star}$ and \\ M. M. S. Metwaly** \\ Agric. Botany Dep., Fac. Agric., Kafrelsheikh Univ., 33516, Kafr El- \\ Sheikh, Egypt. \\ * Agricultural Microbiology ** Agricultural Botany
} \\ 33516 - Kafr Elsheikh, Egypt.
}

\begin{abstract}
The main objective of this study is: Effect of two treatment of bacterial endophytes strains Azotobacter chrocooccum (E1) and Pseudomonas sp. (E2) individually whether as grains soaking and foliar application on some physiological parameters of two wheat plants (Triticum aestivum L.) cultivars (Sakha 93 and Gmiza 9) grown under three levels of irrigation water deficit stress 75,50 and $25 \%$ field capacity. The tested physiological parameters were chlorophyll pigment (chl. a, b and total) contents, relative water content (RWC), leaf water content (LWC), leaf water deficit (LWD), proline content and some major essential elements (NPK) contents. Negative impacts were obtained on the tested wheat cultivars grown under the different irrigation water deficit. Application of Azotobacter chrocooccum (E1) and Pseudomonas sp. (E2) strains individually were carried out by spray foliar and grains soaking treatments increased the tested physiological parameters for two cultivars compared with untreated plant, which could overcome the negative effects of drought stress.

Keyword: Chlorophyll, proline, endophytic bacteria strains, mineral uptake, leaf water deficit, mineral uptake and irrigation water deficit.
\end{abstract}

\section{INTRODUCTION}

Drought is one of the major environmental conditions that adversely affect plant growth, physiological, biochemical changes, including changes of the endogenous phytohormone levels and crop yield (Boyer, 1982).

Due to drought and competing water demands in Egypt have put enormous pressure on irrigation water. Conserve both the quality and quantity of water appropriate strategies will have to be developed to avoid the risk of future water supplies: Reducing irrigation water is to employ practices that improve water productivity (crop yield per unit volume of water used). Among different strategies to cope with drought issues seed priming (presowing seed treatment) is an easy, low cost and low risk technique and this approach has recently been used to overcome the drought problem in agriculture land (Iqbal and Ashraf, 2006). Although priming induced-drought tolerance has been reported in some crops, knowledge about physiological, biochemical and anatomical basis of priming induced-beneficial effects under stressful environment is still in frequent.

Plant growth-promoting bacteria include both free living and symbiotic bacteria, typically found in the soil, that facilitate the growth and development of plants (Glick et al., 1999). This can occur directly to promote plant growth either by providing the plant with a compound that is synthesized 
by the bacterium or by facilitating the uptake of nutrients from the soil. Thus, plant growth-promoting bacteria can directly facilitate the proliferation of plants by fixing atmospheric nitrogen; producing siderophores which can mineral solubilize and provide it to plants; synthesizing phytohormones, such as auxin, cytokinin and gibberellin, which can enhance various stages of plant growth; solubilizing minerals such as phosphorus; and synthesizing enzymes that can modulate plant growth and development (Glick, 2007).

Microbial inoculants that can promote plant growth and productivity is internationally accepted as an alternative source of $\mathrm{N}$-fertilizer. It is environmental friendly and can be used to ensure a sustainable wheat production. In this bio-fertilizer technology new systems are being developed to increase the biological $\mathrm{N}_{2}$ fixation (BNF) with cereals and other nonlegumes by establishing $\mathrm{N}_{2}$-fixing bacteria within the roots (Cocking, 2000). Nitrogen fixation and plant growth promotion by plant growth promoting bacteria are important criteria for an effective bio-fertilizer. Inoculation of associative and free living $\mathrm{N}_{2}$-fixing bacteria have been shown to produce beneficial effects on plant growth, thus they are termed plant growth promoting rhizobacteria (PGPR) (Kloepper et al., 1980; Bashan and Holguin, 1998). Significant increases in crop yields following application of PGPR have been documented under diverse field conditions (Bashan, 1998). They have been widely reported to fix atmospheric nitrogen with grasses and cereals (Dobereiner, 1997) and enhance nutrient uptake (Lin et al., 1983; Murty and Ladha, 1988; Bashan and Holguin, 1998).

Azotobacter sp besides fixing nitrogen it is also secrete certain growth hormones such as IAA, GA and Cytokinins (Coppola, 1971) which promote vegetative growth and root development. Generally, the literature review indicates that there are possibly some positive effects of endophytic bacteria treatment on growth and reproduction of plants.

Wheat production is an essential national target to fill the gap between production and consumption. Production could be increased through cultivation of high yielding cultivars and appropriate agronomic practices (Tawfik et al., 2006). It is obvious that, there found an enormous pressure on irrigation water in Egypt due to drought and competing water demands. Improvement of wheat production under irrigation water deficit (drought) has become important during recent years worldwide. Therefore, the objective of this study was to evaluate two different cultivars of wheat physiology in response to inoculation with Azotobacter chrocooccum (E1) and Pseudomonas sp. (E2) as endophytic bacterial strains under different levels of field capacity.

\section{MATERIALS AND METHODS}

The present investigation was conducted under greenhouse conditions at the Department of Agricultural Botany, Faculty of Agriculture, Kafrelsheikh University, during the two growing winter successive seasons of 2009 / 2010 and 2010 / 2011 to study the impact of certain ecophysiological and microbial studies on the effect of drought stress on some physiological features of wheat plants (Triticum aestivum L.). 


\section{Source of wheat cultivars:}

Wheat grains (Triticum aestivum L.) cultivars Sakha 93 and Gmiza 9 were obtained from Wheat Research Dept. Sakha of Agricultural Research Station, Kafr El-sheaikh, Egypt.

Source of microorganisms:

Two bacterial strains [Azotobacter chrocooccum (E1) and Pseudomonas sp. (E2)] were obtained from Dr. Elsayed Belal, Associate Professor of Agricultural Microbiology, Dep. of Agric. Botany, Fac. of Agriculture, Kafrelsheikh University, where these bacterial strains were isolated in a previous study as entophytic bacteria from wheat plants (unpublished data).

Cultivation of microorganisms:

Azotobacter chrocooccum (E1) and Pseudomonas sp. (E2) were cultivated in nutrient liquid medium. $200 \mathrm{ml}$ nutrient liquid medium were inoculated with $2 \mathrm{ml}$ of a cell suspension of (Azotobacter chrocooccum (E1) or Pseudomonas sp. (E2) (nutrient broth medium, $10^{8} \mathrm{cfu} / \mathrm{ml}$ ) was incubated at $30^{\circ} \mathrm{C}$ and $150 \mathrm{rpm}$ for 3 days. The cultures were incubated at $30{ }^{\circ} \mathrm{C}$ and $150 \mathrm{rpm}$ for 5 days. Thereafter, two bacterial strains were applied on wheat as follow:

\section{Grain treatments}

Two bacterial strains were applied at the time of sowing as seed treatment. Grains were immersed in each bacterial suspension $\left(10^{8} \mathrm{cfu} / \mathrm{ml}\right)$ for $30 \mathrm{~min}$.. Grains were witted with $10 \%$ sugar syrup, and thoroughly mixed with an amount of bacterial suspension $\left(10^{8} \mathrm{cfu} / \mathrm{ml}\right)$ for $30 \mathrm{~min}$. enough to obtain $10^{8} \mathrm{cfu} /$ per gram of grains and then air dried. Grains were then sown in each pot (10 grains / pot). On the other hand, grains wheat were immersed in a manner in $10 \%$ sugar syrup and were thoroughly mixed with an amount of nutrient broth medium (without bacterial growth).

\section{Wheat plant spraying}

Wheat plants (20 days from sowing) were sprayed weekly intervals with bacterial suspension $\left(10^{8} \mathrm{cfu} / \mathrm{ml}\right)$ from each bacterial strains.

Pots, soil preparation and wheat grains sowing:

Each pot $(30 \mathrm{~cm}$ in diameter) contained $8 \mathrm{Kg}$ of air dried clay soil. The chemical analysis was determined by conventional methods, twelve grains / pot were sown at equal distances and depth. After two weeks from sowing, the seedlings were thinned to ten seedlings / pot, three of them were kept for the morphological characters throughout the experimental period.

The soil used in this experiment was fertilized with nitrogen at rate a $360 \mathrm{~kg} / \mathrm{h}$ of urea fertilizer (46\% nitrogen). Super phosphate fertilizer (phosphorus 15\%) was added at a rate of $240 \mathrm{~kg} / \mathrm{ha}$ before sowing. Potassium was not added because the Egyptian soil is rich in this element. Chemical analysis of the soil samples were done before sowing in the two seasons, mechanical and chemical analysis of the experimental soil were determined (Metwaly, 2012) according to Page, (1982) and Klute, (1986).

\section{Chlorophyll pigments measurements:}

Chlorophyll content of the two wheat cultivars was determined after 40, 70 and 130 days from sowing. Chlorophyll A, B and total chlorophyll were determined in the flag leaf lamina using the spectrophotometer method described by Moran and Porath (1980). 


\section{Proline determination :}

Extraction and determination of proline were performedin the flag leaf according to the method of Bates et al., (1973).

\section{Mineral nutrients (NPK) uptake:}

Mineral elements [Nitrogen (N), Phosphorus $(\mathrm{P})$ and Potassium $(\mathrm{K})$ ] were performed on the material which was dried in an electric oven at $70^{\circ} \mathrm{C}$ to constant weight and following determinations were done:

A- Total nitrogen was estimated in the digestion product, using the official Micro-Kjeldahl Method. The percentage of total nitrogen was estimated and crude protein content was calculated by the following equation:

Crude protein \% = Total nitrogen $x 5.83$.

B- Phosphorus was estimated by ascorbic acid method using the calorimetric method as described by Murphy and Riley (1962).

C- Potassium was also estimated in the above mentioned digestion product by using flame photometer according to Jackson (1967).

Plant-water relations:

Relative water content (RWC) was measured according to Schonfeld et al., (1988). Leaf water deficit (LWD) was determined and calculated using a formula according to Kalapos (1994). Leaf water content (LWC) was expressed according to Liu et al., (2004).

\section{Experimental design and statistical analysis:}

The pots were arranged in a randomized complete block design with three replicates in every treatment and ten plants in each pot. Data of the physiological studies were tested by analysis of variance. Duncan's multiple range tests were used for comparisons among treatment mean (Duncan, 1955).

\section{RESULTS AND DISCUSSION}

\section{Physiological studies:}

Drought impacts include physio-biochemical responses growth, yield, membrane integrity, pigment content, osmotic adjustment water relations, and photosynthetic activity (Benjamin and Nielsen, 2006; Praba et al., 2009). Physiological characteristics of wheat cultivars grown under different irrigation water deficit levels (75, 50 and $25 \%$ FC) were studied. Application of two endophytes including $A$. chrocooccum (E1) and Pseudomonas sp. (E2) and the combination between them and irrigation water deficit levels were investigated. These parameters includes chlorophyll pigments (A, B and total $\left.\mu \mathrm{g} / \mathrm{cm}^{2}\right)$, relative water content, leaf water content, mineral uptake $(\mathrm{N}, \mathrm{P}$ and $\mathrm{K} \%$ ), crude protein and proline content (umoles / $\mathrm{g}$ dry weight) were investigated.

\section{Chlorophyll pigments:}

Data presented in Tables (1,2 and 3 ) cleared that, there was a negative impact on chlorophyll pigments (chl. a, b and total) content $(\mu \mathrm{g} /$ $\mathrm{cm}^{2}$ ) by application of different irrigation water deficit levels (75, 50 and $25 \%$ $\mathrm{FC})$. 
J. Plant Production, Mansoura Univ., Vol. 3 (7), July, 2012 
El-Afry, M. M. et al.

2

2074 
J. Plant Production, Mansoura Univ., Vol. 3 (7), July, 2012

3

2075 
Chlorophyll is one of the major chloroplast components for photosynthesis, and relative chlorophyll content has a positive relationship with photosynthetic rate. The decrease in chlorophyll content under drought stress has been considered a typical symptom of oxidative stress and may be the result of pigment photo-oxidation and chlorophyll degradation. Photosynthetic pigments are important to plants mainly for harvesting light and production of reducing powers. Both the chlorophyll $a$ and $b$ are prone to soil dehydration (Farooq et al., 2009). Decreased or unchanged chlorophyll level during drought stress has been reported in many species, depending on the duration and severity of drought (Kyparissis et al., 1995; Zhang and Kirkham, 1996).

Environmental stresses have a direct impact on the photosynthetic apparatus, essentially by disrupting all major components of photosynthesis including the thylakoid electron transport, the carbon reduction cycle and the stomatal control of the $\mathrm{CO} 2$ supply, together with an increased accumulation of carbohydrates, peroxidative destruction of lipids and disturbance of water balance (Allen and Ort, 2001).

The decrease in chlorophyll under drought stress is mainly the result of damage to chloroplasts caused by active oxygen species, and related to the reduction in stomatal conductance and transpiration rate (Chartzoulakis, et al. 1999). Prolonged water stress which limited photosynthesis also led to less of sucrose phosphate synthetase activity (Vassey and Sharky, 1989 and Dubey and Singh, 1999). Furthermore, water deficit induced reduction in chlorophyll content has been ascribed to loss of chloroplast membranes, excessive swelling, distortion of the lamellae vesiculation, and the appearance of lipid droplets (Kaiser et al., 1981). Low concentrations of photosynthetic pigments can directly limit photosynthetic potential and hence primary production (Anjum, et al., 2011).

The wheat cultivars treated with the two bacterial endophytes strains (A. chrocooccum (E1) and Pseudomonas sp. (E2)) had increased significantly chlorophyll pigment content $\left(\mu \mathrm{g} / \mathrm{cm}^{2}\right)$ after 40 and 70 days from sowing. These results were compared with control (100\% FC) without endophytes treatment. The increasing percentage of chl. a $\left(\mu \mathrm{g} / \mathrm{cm}^{2}\right)$ for Gmiza 9 cultivar by application of bacterial endophytes was $13.10 \%$ under normal irrigation water (100\% FC). On the other hand, for Sakha 93 cultivar the percentage of increasing was $15.85 \%$ compared with control treatment. Application of $A$. chrocooccum (E1) and Pseudomonas sp. (E2) in combination with the different tested irrigation water deficit levels, increased significantly in chlorophyll content $\left(\mu \mathrm{g} / \mathrm{cm}^{2}\right)$ Gmiza 9 after 40 and 70 days from sowing. On the other hand, the results for Gmiza 9 cultivar were insignificant due to application of Pseudomonas sp. (E2) as a foliar spraying in combination with the water deficit stress percentage after 40 days from sowing during the both seasons. Auxin is recognized as a key factor, which is directly beneficial of plant. The role of microorganisms as plant growth stimulators is widespread in nature, especially in relation to a group of plant hormones that are implicated in the regulation of diverse biological processes including cell division, elongation, differentiation, root elongation and tropistic responses (Spaepen, et al., 2007). Moreover, Cytokinin stimulates the 
synthesis of chlorophyll pigments ( Jelić and Bogdanović, 1989). In addition, increasing in wheat cultivars treated with endophytic strains was due to the enhancement of essential elements uptake especially nitrogen element $\left(\mathrm{N}_{2}\right)$. Nitrogen is necessary for chlorophyll synthesis and as part of chlorophyll molecules, is the focal point of photosynthesis. Also, $\mathrm{N}_{2}$ is an essential component of amino acids, which building blocks of protein.

\section{Proline content $\left(\mu \mathrm{molg}^{-1}\right)$ :}

Proline content of the leaves was significantly affected by drought stress and increased by declining the water availability in the soil. Data presented in Table (4) cleared that, all used irrigation water deficit treatments increased proline content $(\mu \mathrm{mol} / \mathrm{g})$ in the tested wheat cultivars leaves compared to well-irrigated plants (control $100 \% \mathrm{FC}$ ) during the both growing seasons. Moreover, generally the increasing proline content $(\mu \mathrm{mol} / \mathrm{g})$ for Gmiza 9 cultivar by application of bacterial endophytes was about 25.43, 15.13 and $29.43 \%$ under irrigation water deficit level (75, 50 and $25 \%$ FC) respectively. On the other hand, for Sakha 93 cultivar the percentage was about 23.89, 18.02 and $53.42 \%$ under irrigation water deficit levels $(75,50$ and $25 \%$ FC) respectively.

Plants accumulate different types of organic and inorganic solutes in the cytosol to lower osmotic potential thereby maintaining cell turgor (Rhodes and Samaras, 1994). Under drought, the maintenance of leaf turgor may also be achieved by the way of osmotic adjustment in response to the accumulation of proline, sucrose, soluble carbohydrates, glycinebetaine, and other solutes in cytoplasm improving water uptake from drying soil. The process of accumulation of such solutes under drought stress is known as osmotic adjustment which strongly depends on the rate of plant water stress. Wheat is marked by low level of these compatible solutes and the accumulation and mobilization of proline was observed to enhance tolerance to water stress (Nayyar and Walia, 2003). Of these solutes, proline is the most widely studied because of its considerable importance in the stress tolerance. Proline accumulation is the first response of plants exposed to water-deficit stress in order to reduce injury to cells. Progressive drought stress induced a considerable accumulation of proline in water stressed maize plants. The proline content increased as the drought stress progressed and reached a peak as recorded after 10 days stress, and then decreased under severe water stress as observed after 15 days of stress (Anjum et al., 2011b).

Moreover, proline promotes the production of cytokinins which improved plant growth (Shetty, et al., 1992). Proline can protect plant cells from oxidative damage by scavenging reactive oxygen species (Shao, et al., 2008). It was found in wheat that $\mathrm{Ca}$ appeared to reduce the devastating effects of stress by elevating the content of proline, thus improving the water status and growth of seedlings and minimizing the injury to membranes (Nayyar and Walie 2003).

Water relations:

Concerning wheat cultivars relative water content (RWC), leaf water content (LWC) and leaf water deficit (LWD), data presented in Tables (4, 5 ) showed that, the treatments of irrigation water deficit in the present study 
decreased (RWC), leaf water content and increased leaf water deficit during the both growing season. These results were compared with control (100\% FC) treatment.

Relative water content (RWC), leaf water potential, stomatal resistance, rate of transpiration, leaf temperature and canopy temperature are important characteristics that influence plant water relations. A decrease in the relative water content (RWC) and leaf water content (LWC) in response to drought stress has been noted in wide variety of plants as reported by Nayyar and Gupta (2006). When leaves are subjected to drought, leaves exhibit large reductions in RWC and water potential. Exposure of plants to drought stress substantially decreased the leaf water potential, relative water content and transpiration rate, with a concomitant increase in leaf temperature (Siddique et al., 2001). RWC related to water uptake by the roots as well as water loss by transpiration. It is well known that leaf water status always interacts with stomatal conductance and a good correlation between leaf water potential and stomatal conductance always exists, even under drought stress. It is now clear that there is a drought-induced root-to-leaf signaling, which is promoted by soil drying through the transpiration stream, resulting in stomatal closure.

In this respect application of two bacterial endophytes $A$. chrocooccum (E1) and Pseudomonas sp. (E2) increased significantly wheat cultivars RWC, LWC and reduced LWD compared with untreated plants during the both seasons. The increasing percentage of RWC for Gmiza 9 cultivar by application of bacterial endophytes was about $7.16 \%$ under normal irrigation water (100\% FC). On the other hand, for Sakha 93 cultivar the percentage was about $2.61 \%$ compared with control treatment.

The LWD was increased by increasing levels of irrigation water deficit stress up to $(25 \% \mathrm{FC})$.

In this respect, application of two endophytic bacteria in combination with all irrigation water deficit levels (75, 50 and $25 \%$ FC) increased RWC and LWC and reduced LWD during the both seasons. The obtained results were compared with each of irrigation water deficit level as alone without endophytic bacteria $A$. chrocooccum (E1) and Pseudomonas sp. (E2) treatments. The increasing percentage of RWC for Gmiza 9 cultivar by application of bacterial endophytes was about 14.70, 23.94 and $49.38 \%$ under irrigation water deficit level $(75,50$ and $25 \% \mathrm{FC})$ respectively. On the other hand, for Sakha 93 cultivar the percentage was about 13.57, 25.79 and $54.44 \%$ under irrigation water deficit levels (75, 50 and $25 \%$ FC) respectively. Generally the grains soaking application of two bacterial endophytes was gave the best results, where decreased the leaf water deficit compared with other treatments.

\section{Mineral uptakes:}

It is clear from Table (6) and Fig. (1, 2, 3 and 4) that, the irrigation water deficit stress treatments $(75,50$ and $25 \%$ FC) decreased wheat cultivars uptake of nitrogen $\left(\mathrm{N}_{2} \%\right)$, phosphorus $(\mathrm{P} \%)$ and potassium $(\mathrm{K} \%)$ during the both seasons. These obtained results were compared to wellirrigated plants (control $100 \%$ FC). 
J. Plant Production, Mansoura Univ., Vol. 3 (7), July, 2012 
El-Afry, M. M. et al.

5

2080 
J. Plant Production, Mansoura Univ., Vol. 3 (7), July, 2012

6

2081 


\section{El-Afry, M. M. et al.}

Generally, drought reduces both nutrient uptake by the roots and transport from the roots to the shoots, because of restricted transpiration rates and impaired active transport and membrane permeability (Viets, 1972; Alam, 1999). The decline in soil moisture also results in a decrease in the diffusion rate of nutrients in the soil to the absorbing root surface (Pinkerton and Simpson, 1986; Alam, 1999).

Nitrogen is the mineral element that plants require in the largest amounts and is a constituent of many plant cell components, including amino and nucleic acids and chlorophyll pigments. Therefore, nitrogen deficiency rapidly inhibits plant growth. Phosphorus is a constituent of nucleic acids, phospholipids, phosphoproteins, dinucleotides, and adenosine triphosphate. Hence, $P$ is required for processes including the storage and transfer of energy, photosynthesis, the regulation of some enzymes, and the transport of carbohydrates.

Potassium is an essential factor in protein synthesis, glycolytic enzymes, and photosynthesis; an osmoticum mediating cell expansion and turgor-driven movements; and a competitor of $\mathrm{Na}^{+}$under saline conditions (Marschner, 1995). Because both drought and salinity affect plant growth similarly through water deficit, $\mathrm{K}^{+}$is equally important for maintaining the turgor pressure in plants under either stress. Generally, mineral fertilization not increase growth and yield parameters without sufficient water being available to the plant, and increasing soil-water availability will not increase production without adequate mineral supply. Reducing in mineral uptake under irrigation water deficit may also attributed to a decreased transpiration rate to transport mineral nutrients from root to shoot.

Grains soaking and foliar application of two different endophytic bacteria strains individually under well irrigation (100\% FC) or in combination with all irrigation water deficit stress levels $(75,50$ and $25 \%$ FC) have a positively impact on the tested mineral elements during the both growing seasons. The obtained results were compared with well-irrigated plants (control $100 \%$ FC) treatment without endophytes treatment or each level of irrigation water deficit as alone without endophytes in the combination treatments.

However, plants treated with hormones significantly affected active absorption area, percentage active absorption area ratio, root volume and specific surface area. In general, there was no relationship between the first cropping without hormones application and second cropping with hormones application except percentage active absorption area ratio $\left(-0.999^{*}\right)$ which was negatively correlated.

On the other hand; cytokinins reduced the elongation of roots and the formation of lateral root (Lopez-Bucio et al., 2003; Lohar et al., 2004). Furthermore, Goodwin and Moris (1979) reported that cytokinins produced at the root tip of pea inhibit the lateral root formation, but support lateral stem growth. Zahir et al., (2001) found that exogenous application of cytokinin at the root zone supported luxuriant growth and yield of rice. There are scanty literatures on auxin and potassium interaction, notable work was carried out by Shin et al. (2007). 
Concerning crude protein, data in Table (6) indicate that, there is a negatively impact on crude protein content by all used irrigation water deficit treatments under the present study during the both successive seasons, where decreased as compared with non treated plants. These results are related to the increasing in N2 uptake of the tested wheat cultivars. In this respect the application of two bacterial endophytes $A$. chrocooccum (E1) and Pseudomonas sp. (E2) have a positive impact on $\mathrm{N} \%$, where significantly increased in wheat cultivars during the both seasons. The obtained results were compared with control plants without endophytes treatments. The results are in agreement with (Dobbelaere et al., 2003; Cakmakc, 2005a, 2005b).

The application of two endophytic bacteria in combination with the lowest irrigation water deficit increased the $\mathrm{N} \%$ during the both seasons. On the other side, the increasing for Sakha 93 cultivar by application of Pseudomonas sp. (E2) as a foliar spraying in combination with the same irrigation water deficit treatment was insignificant during the second season.

Application of two bacterial endophytes strains in combination with all other irrigation water deficit increased significantly $\mathrm{N} \%$ during the both seasons as compared with each level of water stress treatment as alone without endophytes treatments.

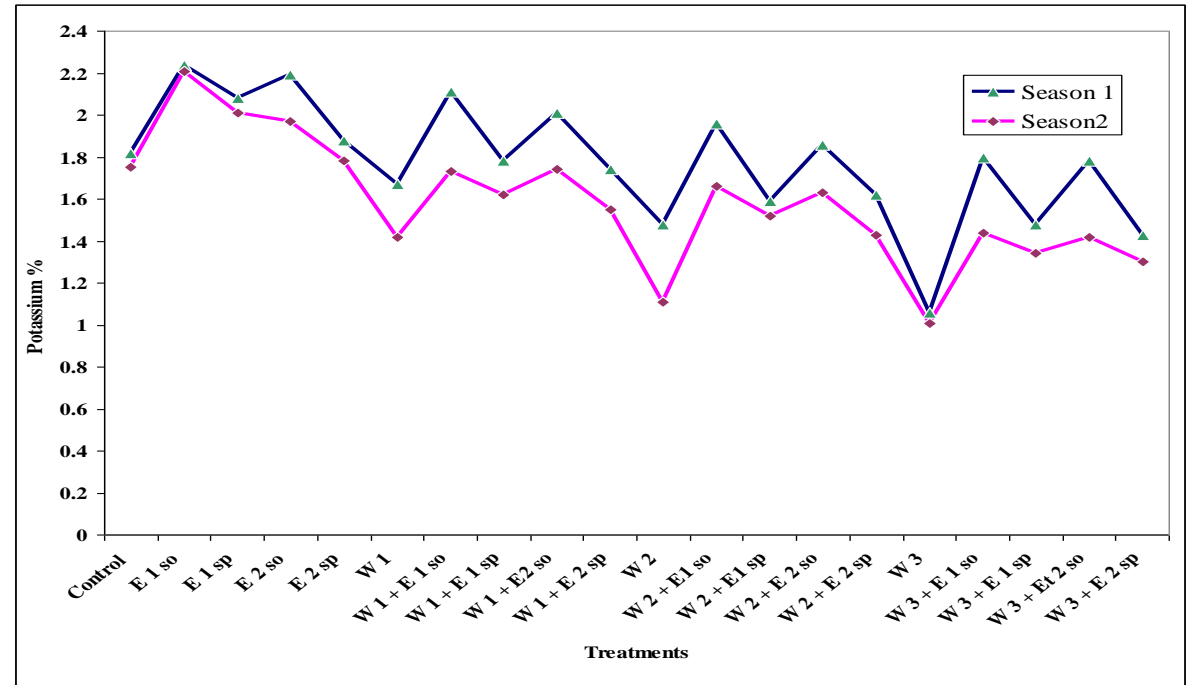

Figure 1: Potassium \% of wheat cultivar Gmiza 9 as affected by different levels of irrigation water deficit and two different endophytes bacteria and their interactions during 2009 / 2010 and 2010 / 2011 seasons. 


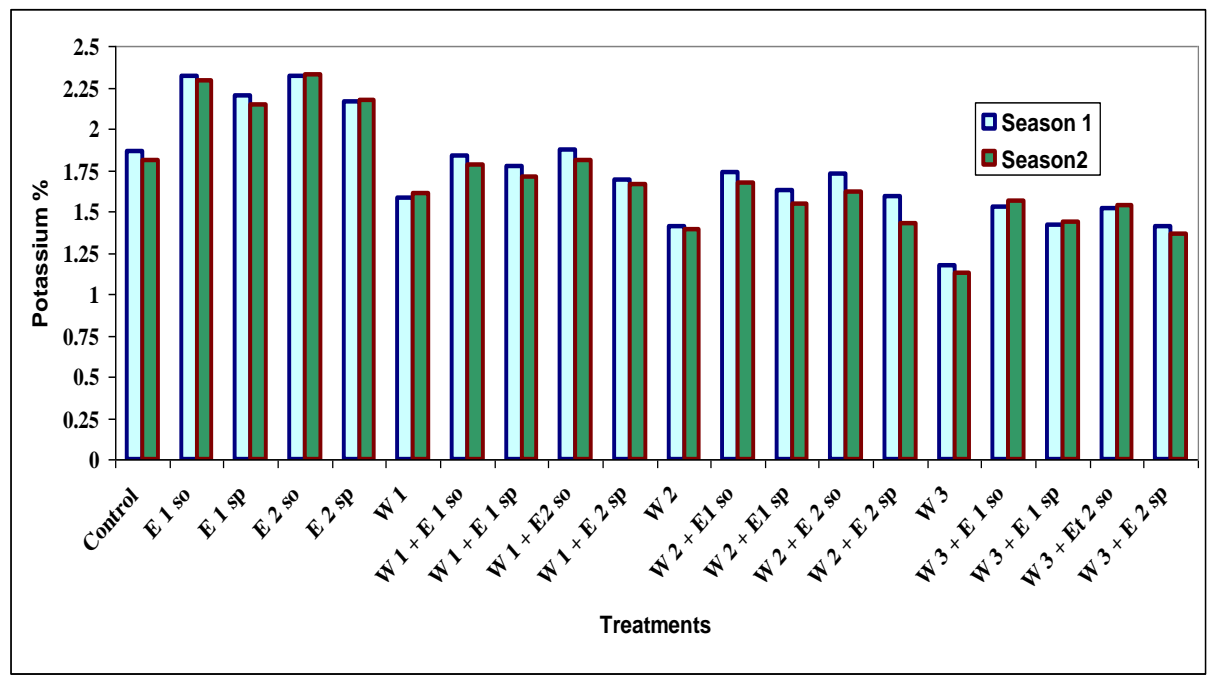

Figure 2: Potassium \% of wheat cultivar Sakha 93 wheat plants as affected by different levels of irrigation water deficit and two different endophytes bacteria and their interactions during 2009 / 2010 and 2010 / 2011 seasons.

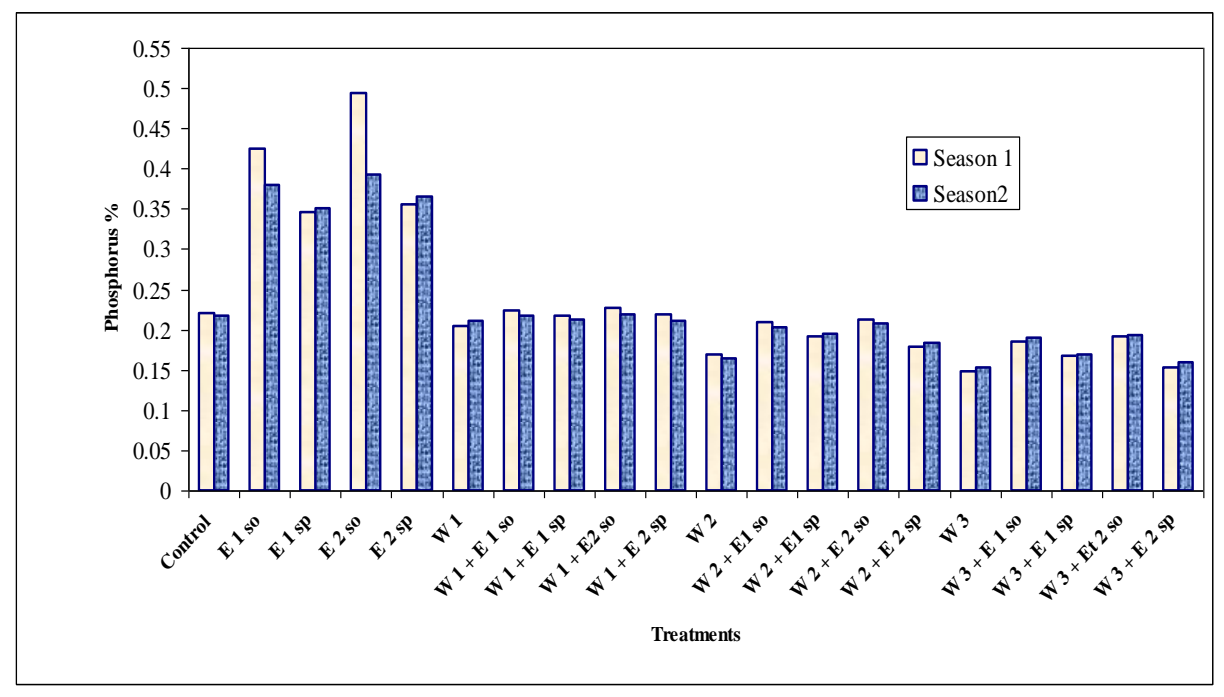

Figure 3: Phosphorus \% of wheat cultivar Gmiza 9 as affected by different levels of irrigation water deficit and two different bacterial endophytes and their interactions during 2009 / 2010 and 2010 / 2011 seasons. 


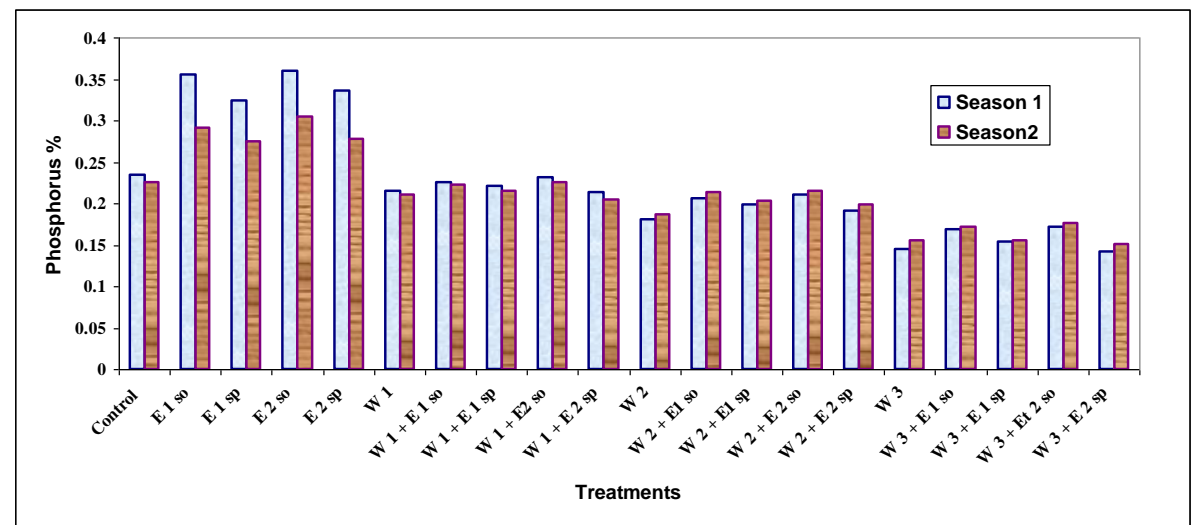

Figure 4: Phosphorus \% of wheat cultivar Sakha 93 as affected by different levels of irrigation water deficit and two different bacterial endophytes and their interactions during 2009 / 2010 and 2010/2011 seasons.

Finally, the obtained results indicated that, the tested irrigation water deficit75, 50 and $25 \%$ FC) decreased wheat cultivars uptake decreased relative water content, leaf water content and increased leaf water deficit. Moreover, chlorophyll pigments (chl. a, b and total) and mineral elements uptake (N2, P and K) were reduced. Application of endophytic bacteria strains [Azotobacter chrocooccum (E1) and Pseudomonas sp. (E2)] individually that carried out by foliar spray and grains soaking treatments increased the tested physiological parameters for the two cultivars during the both seasons. Endophuytic bacterial strains treatments play an important role in protection of wheat plants against the adverse effects of drought stress.

\section{REFERENCES}

Alam, S. M. (1999): Nutrient uptake by plants under stress conditions, in Pessarakli, M.: Handbook of Plant and Crop Stress. Marcel Dekker, New York, pp. 285-314.

Allen, D.J., D.R. Ort (2001). Impact of chilling temperatures on photosynthesis in warm climate plants. Trends Plant Sci., 6: 36-42.

Anjum, S. A. , X. Xie, L. Wang, M. F. Saleem, C. Man and W. Lei (2011). Morphological, physiological and biochemical responses of plants to drought stress. African Journal of Agricultural Research Vol. 6(9), pp. 2026-2032.

Anjum, S. A., L. C. Wang, M. Farooq, I. Khan, L. L. Xue (2011b). Methyl jasmonate-induced alteration in lipid peroxidation, antioxidative defense system and yield in soybean under drought. J. Agron. Crop Sci., doi:10.1111/j.1439-037X.2010.00468.x.

Bashan, Y. and G. Holguin, (1998). Proposal for the division of plant growth promoting rhizobacteria into two classifications: biocontrol-PGPB (plant growth-promoting bacteria) and PGPB. Soil Biol. Biochem., 30: $1225-1228$. 
Bashan, Y., (1998). Inoculants of plant growth promoting rhizobacteria for use in agriculture. Biotechnol. Adv., 16: $729-770$.

Bates, L. S.; R. P. Waldren and I. D. Teare, (1973). Rapid determination of free praline for water stress studies. Plant and soil, 39, 205 - 208.

Benjamin, J. G. and D. C. Nielsen (2006). Water deficit effects on root distribution of soybean, field pea and chickpea. Field Crops Res., 97: 248-253.

Boyer, J. S. (1982). Plant productivity and environment. Science 218, 443448.

Cakmak, R. (2005a). Bitki gelisiminde fosfat cozucu bakterilerin .onemi. Selcuk Univ. Ziraat Faktesi Dergisi 35: 93 - 108.

Cakmak, R. (2005b). Bitki gelisimini tesvik eden rizobakterilerin tarımda kullanımı. Ataturk Univ. Ziraat Fakultesi Dergisi 36: 97- 107.

Chartzoulakis,K., A. Patakas, A.M. Bosabalidis (1999) Changes in water relations, photosynthesis and leaf anatomy induced by intermittent drought in two olive cultivars, Environ. Exp. Bot. 42: 120-133.

Cocking, E. C., (2000). Helping plants get more nitrogen from air. European Rev., 8: $193-200$.

Coppola, S. (1971). Annali di Microbiologia ed Enzimologia., 21: 45 53.

Dobbelaere, S.; J. Vanderleyden and Y. Yaacov Okon, (2003). Plant growthpromoting effects of diazotrophs in the rhizosphere. Critical Rev. Plant Sci. 22: 107 - 149.

Dobereiner, J., (1997). Biological nitrogen fixation in the tropics: social and economic contributions. Soil Biol. Biochem., 29: 771 - 774.

Dubey,R. S. and A.K. Singh(1999). Salinity induces accumulation of soluble sugars and alters the activity of sugar metabolism enzymes in rice plants, Biol. Plantarum 42 (1999) 233-239.

Duncan, B. D. (1955). Multiple range and Multiple F. Test, Biometrics 11: 1 42. tolerance. Euphytica .92: 55 - 61.

Farooq, M.; A. Wahid; N. Kobayashi; D. Fujita; S. M. A. Basra, (2009). Plant drought stress: effects, mechanisms and management. Agron. Sustain. Dev., 29: 185 - 212.

Glick, B. R. (2007). Promotion of plant growth by soil bacteria that regulate plant ethylene levels. Proceedings 33rd PGRSA Annual Meeting.15 21.

Glick, B. R.; L. Changping;, G. Sibdas and E. B. Dumbroff, (1999). Early development of canola seedlings in the presence of the plant growth promoting rhizobacterium Pseudomonas putida GR12 - 2. Soil Biol. Biochem., Vol.29, pp.1233 - 1239.

Goodwin, P. B and S. C. Moris (1979). Application of phytohormones to Pea roots after removal of the apex: effect on lateral root production. Australian Journal of Plant physiology, 6 (2) 195-200.

lqbal, M. and M. Ashraf, (2006). Wheat seed priming in relation to salt tolerance, growth, yield and levels of free salicylic acid and polyamines. Ann. Bot. Fennici, 43: 250 - 259.

Jackson, M. L. (1967). Soil chemical analysis, prentice Hall of India private limited. New Delhe, 115. 
Jelić, G. and M. Bogdanović (1989). Antagonism between abscisic acid and cytokinin in chlorophyllsynthesis in pine seedlings. 61 (2); 197-202.

Kaiser, W.M., G. Kaiser, S. Schöner and S. Neimanis (1981). Photosynthesis under osmotic stress. Differential recovery of photosynthetic activities of stroma enzymes, intact chloroplasts and leaf slices after exposure to high solute concentrations. Planta, 153: 430-435.

Kalapos, T. (1994). Leaf water potential, leaf water deficit relationship for ten species of semiarid grassland community, Plant Soil 160: 105-112

Kloepper, J. W.; J. Leong; M. Teintze and M. N. Schorth, (1980). Enhanced plant growth by siderophores produced by plant growth promoting rhizobacteria. Nature, 286: 885-886.

Klute, A. (1986). Water retention: Laboratory methods. In Methods of soil Analysis, Part 1. 2nd ed. A. Klute (ed.) Agron. Monogr. No. 9. ASA, Madison WI, PP: $653-661$.

Kyparissis, A., Y. Petropoulun and Y. Manetas (1995). Summer survival of leaves in a soft-leaved shrub (Phlomis fruticosa L., Labiatae) under Mediterranean field conditions: avoidance of photoinhibitory damage through decreased chlorophyll contents. J. Exp. Bot., 46: 1825-1831.

Lin, W.; Y. Okon and R. W. Hardy, (1983). Enhanced mineral uptake by Zea mays and Sorghum bicolor roots inoculated with Azospirillum brasilense. Appl. Environ. Microbiol., 45: 1775 -1779.

Liu, H. -S.; Li, F. -M. and Xu, H. (2004) Deficiency of water can enhance root respiration rate of drought-sensitive but not drought-tolerant spring wheat. Agricultural Water Management 64 (2004) 41- 48.

Lohar, D. P., J. E. Schaff, J. G. Laskey, J. J. Kieber, K. K. Bilyeu, and D. M. Bir,(2004). Cytokinins play opposite roles in lateral root formation, and nematode and rhizobial symbioses, Plant J., 38 pp. 203-214.

López-Bucio, J., A. Cruz-Ramirez, and L. Herrera-Estrella (2003). The role of nutrient availability in regulating root architecture. Curr Opin Plant Biol, 6: 280-287.

Marschner, H. (1995): Mineral Nutrition of Higher Plants. Academic Press, London.

Metwaly, M. M. (2012). Ecophysiological and anatomical responses of drought stressed wheat plants (Triticum aestivum L.) treating with some bacterial endophytes. Ph.D.thesis, Faculty of Agriculture, Kafr-El Sheikh University, Kafrelsheikh, Egypt.

Moran, R. and D. Porath (1980). Chlorophyll determination in intact tissues using N, N-Dimetyl formamide. Plant Physiol., 69 pp. 1370-1381.

Murphy, J. and P. J. P. Riely, (1962). A modified single solution method for the determination of phosphate in water. Anl. Chemi. Acta., 27: 31 36.

Murty, M. G. and J. K. Ladha, (1988). Influence of Azospirillum inoculation on the mineral uptake and growth of rice under hydroponics conditions. Plant Soils, 108: 281-285.

Nayyar H and D. Gupta (2006). Differential sensitivity of C3 and C4 plants to water deficit stress: association with oxidative stress and antioxidants. Environ. Exp. Bot. 58: 106-113. 
Nayyar, H and D. P. Walia (2003). Water stress induced proline accumulation in contrasting wheat genotypes as affected by calcium and abscisic acid. Biol. Plant., 46: 275-279.

Page, A. L. (ED) (1982). Methods of soil Analysis. Part 2: Chemical and Microbiological properties, 2nd. Soil Sci. Soc. Am. Inc., Madison, USA.

Praba, M. L., J. E. Cairns, R. C. Babu and H. R. Lafitte (2009). Identification of physiological traits underlying cultivar differences in drought tolerance in rice and wheat. J. Agron. Crop Sci., 195: 30-46.

Rhodes, D. and Y. Samaras (1994). Genetic control of osmoregulation in plants. In cellular and molecular physiology of cell volume regulation. Strange, K. Boca Raton: CRC Press, pp. 347-361.

Schonfeld, M. A.; R. C. Johnson; B. F. Carver and D. W. Mornhinweg, (1988). Water relations in winter wheat as drought resistance indicator. Crop sci. 28: $526-531$.

Shao, H. L. Z. Chu and C. Lu (2008). Kang, Primary antioxidant free radical scavenging and redox signaling pathways in higher plant cell, Int. J. Biol. Sci. 4: 8-14.

Shetty, K., G.Y. Shetty, Y. Nakazaki, K. Yoshioka, Y. Asano and K. Oosawa (1992). Stimulation of benzyladanine-induced in vitro shoot organogenesis in Cucumis melo L. by proline, salicylic acid and aspirin, Plant Sci. 84: 193-199.

Shin, Ryoung, Burch, Adrien, Y., Huppert, Kari A., Tiwari, Shiv, B., Murphy, Angus S., Guilfoyle, Tom J. \& Schachtman, Daniel P. (2007). The Arabidopsis Transcription Factor MYB77 Modulates Auxin Signal Transduction. The Plant Cell, vol. 19: 2440-2453.

Siddique, M. R. B, A. Hamid and M. S. Islam (2001). Drought stress effects on water relations of wheat. Bot. Bull. Acad. Sin., 41: 35-39.

Spaepen, S., J. Vanderleyden and R. Ramans (2007). Indole-3-acetic acid in microbial and microorganism-plant signaling. FEMS Microbiol. Rev. 31: 425-448.

Tawfik, K. P., A. Amany, Bahr and A. K. M. Salem, (2006). Response of Kaller grass (Leptochloa fuscal L.) to biofertilizer inoculation under different levels of sea water irrigation. J. Appl. Sci. Res., 2 (12): 1023 1211.

Vassey, T .L. and T.D. Sharky (1989) Mild water stress of Phaseolus vulgaris plants leads to reduced starch synthesis and extractable sucrose phosphate synthesis activity, Plant Physiol. 89: 1066-1070.

Viets Jr., F. G. (1972): Water deficits and nutrient availability, in Kozlowski, T. T.: Water Deficits and Plant Growth. Vol. III: Plant Responses and Control of Water balance. Academic Press, New York, pp. 217-240.

Zahir, Z. A., H. A. Asghar, and M. Arshad (2001). Cytokinin and its precursors for improving growth and yield of rice. Soil Biology and Biochemistry, 33: 405-408.

Zhang, J., and M. B. Kirkham (1996). Antioxidant response to drought in sunflower and sorghum seedlings. New Phytol., 132: 361-373. 
الاستجابات الفسيولوجية لنباتـات القــح تحت ظـروف الإجهـاد الجفــافي باستخدام بعض البكتريا التي تنمو داخل النبات النبات التبات

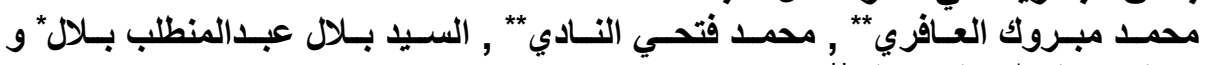

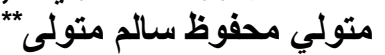

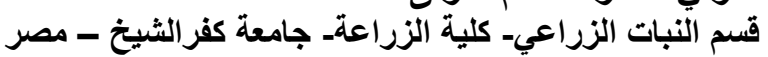

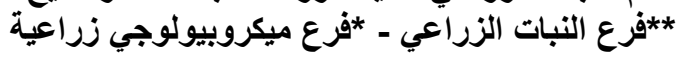

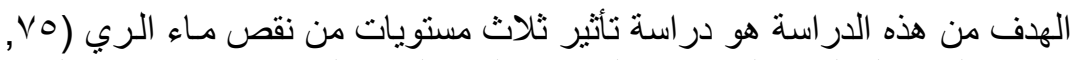

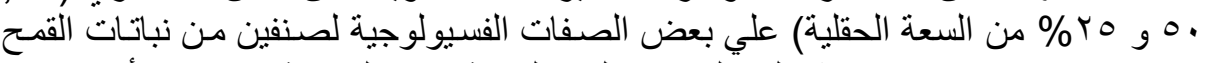

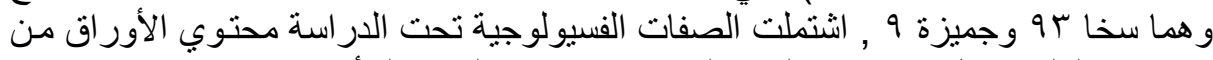

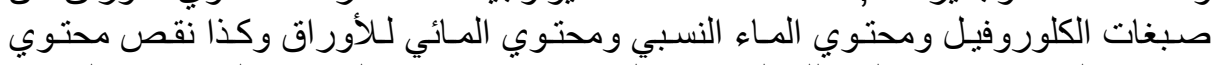

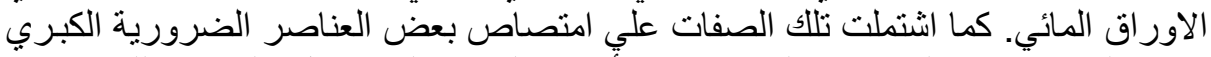

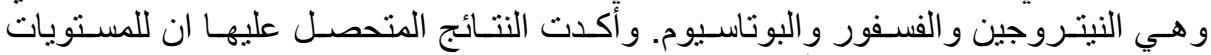

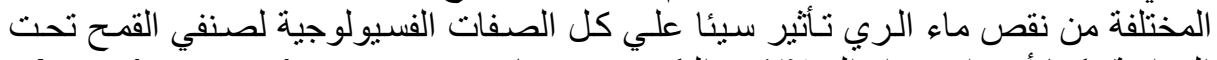

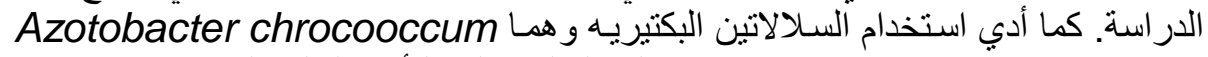
Pseudomonas sp. (E2) و إلي التغلب علي التأثير السلبي لمعاملات نقص ماء

الري تحت الدر اسة.

كلية الزراعة - جامعة المنصورة قام بتحكيم البحث إنمد كلية الزراعة - جامعة المنوفية أ.د / أد / عرفه جندى اصملانه 
El-Afry, M. M. et al.

2090 
Table 1: Chlorophyll a content $\left(\mu \mathrm{g} / \mathrm{cm}^{2}\right)$ in the flag leaf of wheat cultivars Gmiza 9 and Sakha 93 wheat plants as affected by different levels of irrigation water deficit and two bacterial endophytes and their interactions at different stages during 2009 / 2010 and 2010 / 2011 seasons.

\begin{tabular}{|c|c|c|c|c|c|c|c|c|c|c|c|c|c|c|}
\hline \multirow{3}{*}{ Treatment } & \multicolumn{6}{|c|}{ Gmiza 9} & \multicolumn{6}{|c|}{ Sakha 93} & \multirow{3}{*}{$\begin{array}{c}\text { Gmiza } 9 \\
\text { mean of } \\
\text { means }\end{array}$} & \multirow{3}{*}{$\begin{array}{c}\text { Sakha } \\
93 \\
\text { mean of } \\
\text { means }\end{array}$} \\
\hline & \multicolumn{2}{|c|}{$\begin{array}{c}2009 / 20010 \\
\text { season } \\
\text { Chlorophyll a } \\
\text { after }\end{array}$} & \multirow[t]{2}{*}{ Means } & \multicolumn{2}{|c|}{$\begin{array}{c}\text { 2010/2011 season } \\
\text { Chlorophyll a } \\
\text { after }\end{array}$} & \multirow[t]{2}{*}{ Means } & \multicolumn{2}{|c|}{$\begin{array}{c}2009 / 20010 \\
\text { season } \\
\text { Chlorophyll a after }\end{array}$} & \multirow[t]{2}{*}{ Means } & \multicolumn{2}{|c|}{$\begin{array}{c}\text { 2010/2011 season } \\
\text { Chlorophyll a } \\
\text { after }\end{array}$} & \multirow[t]{2}{*}{ Means } & & \\
\hline & 40 days & 70 days & & 40 days & 70 days & & 40 days & 70 days & & 40 days & 70 days & & & \\
\hline Control & $35.09^{\mathrm{E}}$ & $38.81^{C D}$ & 36.7 & $32.44^{\mathrm{C}}$ & $35.49^{C D}$ & 33.97 & $42.43^{\mathrm{CD}}$ & $24.79^{C}$ & 33.61 & $40.01^{B}$ & $19.99^{\mathrm{C}}$ & 30.00 & 35.34 & 31.81 \\
\hline E $1 \mathrm{Gs}$ & $40.42^{\mathrm{AB}}$ & $41.24^{\mathrm{AB}}$ & 40.83 & $41.24^{\mathrm{A}}$ & $40.03^{\mathrm{AB}}$ & 40.64 & $49.73^{\mathrm{A}}$ & $33.35^{\mathrm{A}}$ & 41.54 & $44.42^{\mathrm{A}}$ & $24.24^{\mathrm{AB}}$ & 34.33 & 40.74 & 37.94 \\
\hline E 1 & $38.66^{\mathrm{BC}}$ & $41.83^{\mathrm{A}}$ & 40.25 & $39.79^{\mathrm{AB}}$ & $38.98^{\mathrm{B}}$ & 39.39 & $46.03^{B}$ & $32.33^{\mathrm{A}}$ & 39.18 & $43.79^{A}$ & $23.24^{\mathrm{B}}$ & 33.51 & 39.82 & 36.35 \\
\hline E 2 Gs & $41.58^{\mathrm{A}}$ & $41.34^{A B}$ & 41.46 & $41.11^{\mathrm{A}}$ & $40.58^{A}$ & 40.85 & $46.85^{\mathrm{B}}$ & $33.83^{A}$ & 40.34 & $44.83^{\mathrm{A}}$ & $25.13^{A}$ & 34.98 & 41.16 & 37.66 \\
\hline E 2 Sp & $37.48^{\mathrm{CD}}$ & $39.94^{\mathrm{BC}}$ & 38.71 & $38.57^{\mathrm{B}}$ & $36.65^{\mathrm{C}}$ & 37.61 & $44.06^{\mathrm{C}}$ & $30.66^{\mathrm{B}}$ & 37.36 & $43.03^{\mathrm{A}}$ & $24.09^{A B}$ & 33.56 & 38.16 & 35.46 \\
\hline W 1 & $31.17^{\mathrm{FG}}$ & $32.90^{\mathrm{F}}$ & 32.04 & $27.21^{\mathrm{E}}$ & 30. & 28.81 & 36.7 & 18 & 27.58 & $35.51^{\mathrm{C}}$ & 16 & 25.86 & 30.43 & 26.72 \\
\hline 1 Gs & $35.65^{\mathrm{E}}$ & $37.78^{\mathrm{DE}}$ & 36.72 & $32.77^{\mathrm{C}}$ & $35.16^{\mathrm{DE}}$ & 33.97 & $42.19^{C D}$ & $23.76^{\mathrm{CD}}$ & 32.98 & $39.42^{\mathrm{B}}$ & $18.46^{\mathrm{CD}}$ & 28.94 & 35.35 & 30.96 \\
\hline W $1+$ E 1 Sp & $34.16^{\mathrm{E}}$ & $36.87^{E}$ & 35.52 & $30.42^{\mathrm{D}}$ & $33.88^{\mathrm{E}}$ & 32.15 & $40.49^{\mathrm{DE}}$ & $22.72^{\mathrm{DE}}$ & 31.61 & $34.80^{\mathrm{CD}}$ & $17.27^{\mathrm{DEF}}$ & 26.04 & 33.84 & 28.83 \\
\hline W 1 + E2 Gs & $34.49^{\mathrm{E}}$ & $37.20^{\mathrm{DE}}$ & 35.85 & $32.99^{\mathrm{C}}$ & $34.78^{\mathrm{DE}}$ & 33.89 & $42.31^{\mathrm{CD}}$ & $24.38^{C}$ & 33.35 & $36.13^{\mathrm{C}}$ & $17.89^{\mathrm{DE}}$ & 27.01 & 34.87 & 30.18 \\
\hline W 1 + E 2 Sp & $31.75^{\mathrm{FG}}$ & $34.11^{F}$ & 32.93 & $27.46^{\mathrm{E}}$ & $31.92^{F}$ & 29.69 & $38.99^{\mathrm{EF}}$ & $20.06^{F}$ & 29.53 & $34.08^{\mathrm{CD}}$ & $17.59^{\mathrm{DE}}$ & 25.84 & 31.31 & 27.69 \\
\hline W 2 & $26.05^{\prime}$ & $26.73^{\mathrm{H}}$ & 26.39 & $23.64^{F}$ & $25.14^{\mathrm{JK}}$ & 24.39 & $33.46^{1}$ & $16.02^{\mathrm{K}}$ & 24.74 & $31.58^{\mathrm{EF}}$ & $14.26^{\mathrm{HI}}$ & 22.92 & 25.39 & 23.83 \\
\hline W 2 & $31.97^{F}$ & $32.55^{\mathrm{F}}$ & 32.26 & $29.33^{\mathrm{D}}$ & & 29.19 & 38.6 & $19.89^{F G}$ & 29.26 & $34.51^{\mathrm{CD}}$ & EF & 25.53 & 73 & 27.39 \\
\hline W 2 + E1 Sp & $29.67^{\mathrm{GH}}$ & $27.96^{\mathrm{H}}$ & 28.82 & $26.80^{\mathrm{E}}$ & $27.60^{\prime}$ & 27.20 & $37.27^{\mathrm{FGH}}$ & $21.79^{\mathrm{E}}$ & 29.53 & $33.18^{\mathrm{DE}}$ & $17.39^{\mathrm{DE}}$ & 25.29 & 28.01 & 27.41 \\
\hline E 2 Gs & $29.80^{\mathrm{GH}}$ & $30.86^{\mathrm{G}}$ & 30.33 & $29.89^{D}$ & $28.75^{\mathrm{HI}}$ & 29.32 & $37.96^{\mathrm{FG}}$ & $22.42^{\mathrm{DE}}$ & 30.19 & $33.17^{\mathrm{DE}}$ & $16.78^{\mathrm{DEF}}$ & 24.98 & 29.83 & 27.59 \\
\hline W $2+E 2 S p$ & $29.34^{\mathrm{H}}$ & $30.09^{\mathrm{G}}$ & 29.72 & $25.99^{\mathrm{E}}$ & $24.49^{\mathrm{KL}}$ & 25.24 & $35.50^{\mathrm{H}}$ & $19.11^{\mathrm{FG}}$ & 27.31 & $30.65^{F}$ & $15.64^{\mathrm{FGH}}$ & 23.15 & 26.98 & 25.23 \\
\hline W 3 & $19.29^{k}$ & $21.88^{J}$ & 20.58 & $14.79^{\mathrm{H}}$ & $19.71^{\mathrm{N}}$ & 17.25 & $28.43^{\mathrm{L}}$ & $13.79^{L}$ & 21.11 & $23.33^{1}$ & 11 & 17.50 & 2 & 19.31 \\
\hline W $3+E 1$ Gs & $24.97^{1 \mathrm{~J}}$ & $27.27^{\mathrm{H}}$ & 26.12 & $23.95^{F}$ & $26.19^{J}$ & 25.07 & $31.61^{J}$ & $17.87^{\mathrm{HIJ}}$ & 24.74 & $26.91^{\mathrm{G}}$ & $14.68^{\mathrm{GHI}}$ & 20.79 & 25.59 & 22.77 \\
\hline W 3 + E 1 Sp & $23.15^{J}$ & $26.53^{\mathrm{H}}$ & 24.84 & $23.55^{\mathrm{F}}$ & $23.58^{\mathrm{LM}}$ & 23.57 & $31.21^{\mathrm{JK}}$ & $16.91^{\mathrm{IJK}}$ & 24.06 & $25.39^{\mathrm{H}}$ & $13.85^{\prime}$ & 19.62 & 24.21 & 21.84 \\
\hline W 3 + E 2 Gs & $24.48^{\mathrm{IJ}}$ & $27.27^{\mathrm{H}}$ & 25.89 & $19.47^{\mathrm{G}}$ & $24.47^{\mathrm{KL}}$ & 21.97 & $31.12^{\mathrm{JK}}$ & $18.04^{\mathrm{HI}}$ & 24.58 & $26.43^{\mathrm{G}}$ & $14.49^{\mathrm{HI}}$ & 20.46 & 23.93 & 22.52 \\
\hline W 3 + E 2 Sp & $20.49^{\mathrm{K}}$ & $24.97^{\prime}$ & 22.73 & $16.00^{\mathrm{H}}$ & $22.46^{\mathrm{M}}$ & 19.23 & $29.51^{\mathrm{KL}}$ & $16.27^{\mathrm{JK}}$ & 22.89 & $23.92^{\mathrm{HI}}$ & $13.27^{1}$ & 18.59 & 20.98 & 20.74 \\
\hline
\end{tabular}


Table 2: Chlorophyll b content $\left(\mu \mathrm{g} / \mathrm{Cm}^{2}\right)$ in the flag leaf of wheat cultivars Gmiza 9 and Sakha 93 wheat plants as affected by different levels of irrigation water deficit and two bacterial endophytes and their interactions at different stages during 2009 / 2010 and 2010 / 2011 seasons.

\begin{tabular}{|c|c|c|c|c|c|c|c|c|c|c|c|c|c|c|}
\hline \multirow{3}{*}{ Treatment } & \multicolumn{6}{|c|}{ Gmiza 9} & \multicolumn{6}{|c|}{ Sakha 93} & \multirow{3}{*}{$\begin{array}{c}\text { Gmiza } 9 \\
\text { mean of } \\
\text { means }\end{array}$} & \multirow{3}{*}{$\begin{array}{c}\text { Sakha } 93 \\
\text { mean of } \\
\text { means }\end{array}$} \\
\hline & \multicolumn{2}{|c|}{\begin{tabular}{|c|}
$2009 / 20010$ \\
season \\
$\begin{array}{c}\text { Chlorophyll b } \\
\text { after }\end{array}$ \\
\end{tabular}} & \multirow[t]{2}{*}{ Means } & \multicolumn{2}{|c|}{$\begin{array}{l}\text { 2010/2011 season } \\
\text { Chlorophyll b after }\end{array}$} & \multirow[t]{2}{*}{ Means } & \multicolumn{2}{|c|}{$\begin{array}{c}2009 / 20010 \\
\text { season } \\
\text { Chlorophyll b after }\end{array}$} & \multirow[t]{2}{*}{ Means } & \multicolumn{2}{|c|}{$\begin{array}{l}\text { 2010/2011 season } \\
\text { Chlorophyll b after }\end{array}$} & \multirow[t]{2}{*}{ Means } & & \\
\hline & 40 & 70 & & 40 & 70 & & 40 & 70 & & 40 & 70 & & & \\
\hline Control & $17.72^{\mathrm{E}}$ & $17.56^{\mathrm{CD}}$ & 17.64 & $16.47^{\mathrm{C}}$ & $15.92^{\mathrm{CD}}$ & 16.19 & $19.29^{\mathrm{CD}}$ & $11.27^{\mathrm{C}}$ & 15.28 & $18.18^{\mathrm{B}}$ & $9.09^{C}$ & 13.64 & 16.92 & 14.46 \\
\hline E 1 Gs & $20.41^{\mathrm{AB}}$ & $18.67^{\mathrm{AB}}$ & 19.54 & $20.93^{A}$ & $17.95^{A B}$ & 19.44 & $22.60^{A}$ & $15.16^{\mathrm{A}}$ & 18.88 & $20.18^{A}$ & $11.02^{A B}$ & 15.60 & 19.49 & 17.24 \\
\hline E $1 \mathrm{Sp}$ & $19.53^{\mathrm{BC}}$ & $18.93^{\mathrm{A}}$ & 19.23 & $20.19^{A B}$ & $17.48^{\mathrm{B}}$ & 18.84 & $20.92^{\mathrm{B}}$ & $14.69^{\mathrm{A}}$ & 17.81 & $19.91^{\mathrm{A}}$ & $10.57^{\mathrm{B}}$ & 15.24 & 19.04 & 16.53 \\
\hline E 2 Gs & $21.00^{A}$ & $18.71^{\mathrm{AB}}$ & 19.86 & $20.87^{\mathrm{A}}$ & $18.19^{A}$ & 19.53 & $21.29^{\mathrm{B}}$ & $15.38^{\mathrm{A}}$ & 18.34 & $20.38^{A}$ & $11.42^{\mathrm{A}}$ & 15.90 & 19.69 & 17.12 \\
\hline E 2 Sp & $18.93^{\mathrm{CD}}$ & $18.07^{\mathrm{BC}}$ & 18.50 & $19.58^{\mathrm{B}}$ & $16.43^{\mathrm{C}}$ & 18.01 & $20.03^{\mathrm{C}}$ & $13.93^{\mathrm{B}}$ & 16.98 & $19.56^{A}$ & $10.95^{A B}$ & 15.26 & 18.26 & 16.12 \\
\hline W 1 & $15.74^{\mathrm{FGH}}$ & $14.89^{\mathrm{F}}$ & 15.32 & $13.81^{\mathrm{E}}$ & $13.64^{\mathrm{G}}$ & 13.73 & $16.70^{\mathrm{GH}}$ & $8.36^{\mathrm{GH}}$ & 12.53 & $16.14^{\mathrm{C}}$ & $7.37^{\mathrm{EFG}}$ & 11.76 & 14.53 & 12.15 \\
\hline W1+E1 Gs & $18.00^{\mathrm{DE}}$ & $17.09^{\mathrm{DE}}$ & 17.55 & $16.64^{\mathrm{C}}$ & $15.77^{\mathrm{DE}}$ & 16.21 & $19.18^{\mathrm{CD}}$ & $10.79^{\mathrm{CD}}$ & 14.99 & $17.92^{\mathrm{B}}$ & $8.39^{\mathrm{CD}}$ & 13.16 & 16.88 & 14.08 \\
\hline W1+E1 Sp & $17.25^{\mathrm{E}}$ & $16.68^{\mathrm{E}}$ & 16.97 & $15.44^{\mathrm{D}}$ & $15.19^{\mathrm{E}}$ & 15.32 & $18.40^{\mathrm{DE}}$ & $10.33^{\mathrm{DE}}$ & 14.37 & $15.82^{\mathrm{CD}}$ & $7.85^{\mathrm{DEF}}$ & 11.84 & 16.15 & 13.11 \\
\hline W1+E2 Gs & $17.42^{\mathrm{E}}$ & $16.83^{\mathrm{DE}}$ & 17.13 & $16.74^{\mathrm{C}}$ & $15.59^{\mathrm{DE}}$ & 16.17 & $19.23^{\mathrm{CD}}$ & $11.08^{\mathrm{C}}$ & 15.16 & $16.42^{\mathrm{C}}$ & $8.13^{\mathrm{DE}}$ & 12.28 & 16.65 & 13.72 \\
\hline W1+E2 Sp & $16.03^{\mathrm{FG}}$ & $15.44^{\mathrm{F}}$ & 15.74 & $13.94^{\mathrm{E}}$ & $14.32^{\mathrm{F}}$ & 14.13 & $17.72^{\mathrm{EF}}$ & $9.12^{F}$ & 13.42 & $15.49^{\mathrm{CD}}$ & $7.99^{\mathrm{DE}}$ & 11.74 & 14.94 & 12.58 \\
\hline w 2 & $13.15^{1}$ & $12.09^{\mathrm{H}}$ & 12.62 & $12.00^{\mathrm{F}}$ & $11.27^{\mathrm{JK}}$ & 11.6 & $15.21^{1}$ & $7.28^{\mathrm{K}}$ & 11.25 & $14.36^{\mathrm{EF}}$ & $6.48^{\mathrm{HI}}$ & 10.42 & 12.13 & 10.84 \\
\hline W2+ & $16.14^{\mathrm{F}}$ & $14.73^{\mathrm{F}}$ & 15.44 & $14.88^{\mathrm{D}}$ & $13.03^{\mathrm{H}}$ & 13.9 & $17.56^{\mathrm{EFG}}$ & $9.04^{\mathrm{FG}}$ & 13.30 & $15.69^{\mathrm{CD}}$ & 7.5 & 11.61 & 14.70 & 12.46 \\
\hline W2+E1 Sp & $14.98^{\mathrm{GH}}$ & $12.65^{\mathrm{H}}$ & 13.82 & $13.61^{\mathrm{E}}$ & $12.38^{\prime}$ & 12.99 & $16.94^{\mathrm{FGH}}$ & $9.90^{\mathrm{E}}$ & 13.42 & $15.08^{\mathrm{DE}}$ & $7.91^{\mathrm{DE}}$ & 11.49 & 13.41 & 12.46 \\
\hline W2+E2 Gs & $15.05^{\mathrm{GH}}$ & $13.96^{\mathrm{G}}$ & 14.51 & $15.17^{\mathrm{D}}$ & $12.89^{H I I}$ & 14.03 & $17.25^{\mathrm{FG}}$ & $10.19^{\mathrm{DE}}$ & 13.72 & $15.08^{\mathrm{DE}}$ & $7.63^{\mathrm{DEF}}$ & 11.36 & 14.27 & 12.54 \\
\hline W2+E2 Sp & $14.82^{\mathrm{H}}$ & $13.62^{\mathrm{G}}$ & 14.22 & $13.19^{\mathrm{E}}$ & $10.98^{\mathrm{KL}}$ & 12.09 & $16.14^{\mathrm{H}}$ & $8.68^{\mathrm{FGH}}$ & 12.41 & $13.93^{\mathrm{F}}$ & $7.11^{\mathrm{FGH}}$ & 10.52 & 13.16 & 11.47 \\
\hline & $9.74^{\mathrm{K}}$ & $9.89^{\jmath}$ & 9.82 & $7.51^{\mathrm{H}}$ & $8.84^{\mathrm{N}}$ & 8.1 & $12.92^{\mathrm{L}}$ & $6.27^{\mathrm{L}}$ & 9.59 & 10.6 & $5.30^{\mathrm{J}}$ & 7.95 & $9 .($ & 8.77 \\
\hline W3+E1 Gs & $12.61^{1 \mathrm{~J}}$ & $12.34^{\mathrm{H}}$ & 12.48 & $12.16^{\mathrm{F}}$ & 11.7 & 11.95 & 14.3 & $8.12^{\mathrm{HIJ}}$ & 11.25 & $12.23^{\mathrm{G}}$ & $6.67^{\mathrm{GHI}}$ & 9. & 12.22 & 10.35 \\
\hline W3+E1 Sp & $11.69^{\mathrm{J}}$ & $12.01^{\mathrm{H}}$ & 11.85 & $11.95^{\mathrm{F}}$ & $10.57^{\mathrm{LM}}$ & 11.26 & $14.19^{\mathrm{JK}}$ & $7.69^{\mathrm{IJK}}$ & 10.94 & $11.54^{\mathrm{GH}}$ & $6.29^{1}$ & 8.92 & 11.56 & 9.93 \\
\hline W3+E2 Gs & $12.37^{1 \mathrm{I}}$ & $12.34^{\mathrm{H}}$ & 12.36 & $9.88^{G}$ & $10.97^{\mathrm{KL}}$ & 10.43 & $14.14^{\mathrm{JK}}$ & $8.20^{\mathrm{HI}}$ & 11.17 & $12.01^{\mathrm{G}}$ & $6.59^{H 1}$ & 9.30 & 11.39 & 10.24 \\
\hline W3+E2 Sp & $10.35^{\mathrm{K}}$ & $11.29^{\prime}$ & 10.82 & $8.12^{\mathrm{H}}$ & $10.07^{\mathrm{M}}$ & 9.09 & $13.41^{\mathrm{KL}}$ & $7.39^{\mathrm{JK}}$ & 10.40 & $10.87^{\mathrm{HI}}$ & $6.03^{1}$ & 8.45 & 9.96 & 9.43 \\
\hline
\end{tabular}

E1 = Azotobacter chrocooccum E2 = Pseudomonas sp Gs = Grains soaking Sp = foliar application control = 100 \% field capacity W1 = 75\% field capacity W2 $=50 \%$ field capacity W3 $=25 \%$ field capacity

Values within the same vertical areas with the same letter are not significantly different at $5 \%$ probability level by Duncan's Multiple Range Test 
Table 3: Total chlorophyll content $\left(\mu \mathrm{g} / \mathrm{cm}^{2}\right)$ in the flag leaf of wheat cultivars Gmiza 9 and Sakha 93 wheat plants as affected by different levels of irrigation water deficit and two bacterial endophytes and their interactions at different stages during 2009 / 2010 and 2010 / 2011 seasons.

\begin{tabular}{|c|c|c|c|c|c|c|c|c|c|c|c|c|c|c|}
\hline \multirow{3}{*}{ Treatment } & \multicolumn{6}{|c|}{$\begin{array}{r}\text { Gmiza } 9 \\
\end{array}$} & \multicolumn{6}{|c|}{ Sakha 93} & \multirow{3}{*}{$\begin{array}{c}\text { Gmiza } 9 \\
\text { mean of } \\
\text { means }\end{array}$} & \multirow{3}{*}{$\begin{array}{c}\text { Sakha } 93 \\
\text { mean of } \\
\text { means }\end{array}$} \\
\hline & \multicolumn{2}{|c|}{\begin{tabular}{|c|}
$\frac{2009 / 20010}{\text { season }}$ \\
$\begin{array}{c}\text { Total chlorophyll } \\
\text { after }\end{array}$ \\
\end{tabular}} & \multirow[t]{2}{*}{ Means } & \multicolumn{2}{|c|}{ 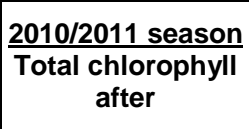 } & \multirow[t]{2}{*}{ Means } & \multicolumn{2}{|c|}{ 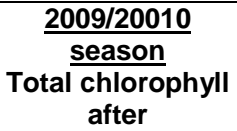 } & \multirow[t]{2}{*}{ Means } & \multicolumn{2}{|c|}{ 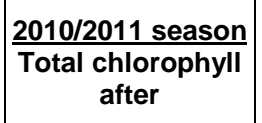 } & \multirow[t]{2}{*}{ Means } & & \\
\hline & 40 & 70 & & 40 & 70 & & 40 & 70 & & 40 & 70 & & & \\
\hline Control & $52.82^{\mathrm{E}}$ & $56.37^{\mathrm{CD}}$ & 54.59 & $48.90^{C}$ & $51.41^{\mathrm{CD}}$ & 50.16 & $58.87^{\mathrm{EF}}$ & $36.07^{\mathrm{C}}$ & 47.47 & $58.19^{\mathrm{B}}$ & $29.08^{\mathrm{C}}$ & 43.59 & 52.38 & 45.53 \\
\hline E 1 Gs & $60.83^{\mathrm{AB}}$ & $59.91^{\mathrm{AB}}$ & 60.37 & $62.17^{\mathrm{A}}$ & $57.99^{\mathrm{AB}}$ & 60.09 & $70.71^{\mathrm{A}}$ & $48.51^{\mathrm{A}}$ & 59.61 & $64.61^{\mathrm{A}}$ & $35.26^{\mathrm{AB}}$ & 49 & 60.23 & 54.78 \\
\hline & $58.19^{\mathrm{BC}}$ & $60.75^{\mathrm{A}}$ & 59.47 & $59.98^{\mathrm{AB}}$ & $56.47^{\mathrm{B}}$ & 58.23 & $65.57^{\mathrm{BC}}$ & $47.02^{\mathrm{A}}$ & 56.29 & $63.69^{\mathrm{A}}$ & $33.81^{\mathrm{B}}$ & & & 52.52 \\
\hline E 2 Gs & $62.56^{\mathrm{A}}$ & $60.05^{\mathrm{AB}}$ & 61.31 & $61.97^{\mathrm{A}}$ & $58.78^{\mathrm{A}}$ & 60.38 & $68.14^{A B}$ & $49.21^{\mathrm{A}}$ & 58.68 & $65.20^{\mathrm{A}}$ & $36.55^{\mathrm{A}}$ & 50.88 & 60.85 & 54.78 \\
\hline E 2 Sp & $56.41^{\mathrm{CD}}$ & $58.01^{\mathrm{BC}}$ & 57.21 & $58.14^{\mathrm{B}}$ & $53.08^{\mathrm{C}}$ & 46.61 & $64.09^{\mathrm{CD}}$ & $44.59^{\mathrm{B}}$ & 54.34 & $62.58^{\mathrm{A}}$ & $33.04^{A B}$ & 47.81 & 51.91 & 51.08 \\
\hline W 1 & $46.91^{\mathrm{FGH}}$ & $47.78^{\mathrm{F}}$ & 47.35 & $41.03^{\mathrm{E}}$ & $44.04^{\mathrm{G}}$ & 42.54 & $53.45^{\mathrm{HI}}$ & $26.76^{\mathrm{GHI}}$ & 40.11 & $51.65^{\mathrm{C}}$ & 23.5 & 37.61 & 44.95 & 38.86 \\
\hline W1+E1 Gs & $53.66^{\mathrm{DE}}$ & $54.88^{\mathrm{DE}}$ & 54.27 & $49.41^{\mathrm{C}}$ & $50.93^{\mathrm{DE}}$ & 50.17 & $61.37^{\mathrm{DE}}$ & $34.56^{\mathrm{CD}}$ & 47.97 & & & 42. & 52.22 & 45.04 \\
\hline W1+E1 Sp & $51.42^{\mathrm{E}}$ & $53.55^{\mathrm{E}}$ & 52.49 & $45.87^{D}$ & $49.07^{\mathrm{E}}$ & 47.47 & $58.89^{\mathrm{EF}}$ & $33.05^{\mathrm{DE}}$ & 45.97 & $50.62^{\mathrm{CD}}$ & $25.12^{\mathrm{DEF}}$ & 37.87 & 49.98 & 41.92 \\
\hline W1+E2 Gs & $51.92^{\mathrm{E}}$ & $54.03^{\mathrm{DE}}$ & 52.98 & $49.73^{\mathrm{C}}$ & $50.38^{\mathrm{DE}}$ & 50.06 & $61.54^{\mathrm{DE}}$ & $35.46^{\mathrm{C}}$ & 48.50 & $52.55^{\mathrm{C}}$ & $26.03^{\mathrm{DE}}$ & 39.29 & 51.52 & 43.89 \\
\hline W1+E2 Sp & $47.78^{\mathrm{FG}}$ & $49.55^{\mathrm{F}}$ & 48.67 & $41.39^{\mathrm{E}}$ & $46.24^{\mathrm{F}}$ & 43.82 & $56.71^{\mathrm{FG}}$ & $29.17^{\mathrm{F}}$ & 42.94 & $49.57^{\mathrm{CD}}$ & $25.59^{\mathrm{DE}}$ & 37.58 & 46.25 & 40.26 \\
\hline W 2 & $39.20^{1}$ & $38.82^{\mathrm{H}}$ & 38.76 & $35.64^{\mathrm{F}}$ & $36.41^{\mathrm{JK}}$ & 36.0 & 48.6 & $23.31^{\mathrm{K}}$ & 35. & $45.94^{\mathrm{EF}}$ & $20.74^{\mathrm{HI}}$ & 33.34 & 37.39 & 34.67 \\
\hline W2+E1 Gs & $48.11^{F}$ & $47.27^{\mathrm{F}}$ & 47 & 44 & $42.07^{\mathrm{H}}$ & 43. & $56.18^{\mathrm{FGH}}$ & $28.93^{\mathrm{FG}}$ & 42. & $9^{C D}$ & $24.06^{\mathrm{EF}}$ & 37.13 & 45.42 & 39.85 \\
\hline W2+E1 Sp & $44.56^{\mathrm{GH}}$ & $40.61^{\mathrm{H}}$ & 42.59 & $40.41^{\mathrm{E}}$ & $39.98^{1}$ & 40.19 & $54.21^{\mathrm{GHI}}$ & $31.69^{\mathrm{E}}$ & 42.95 & $48.26^{\mathrm{DE}}$ & $25.29^{\mathrm{DE}}$ & 36.78 & 41.39 & 39.69 \\
\hline W2+E2 Gs & $44.86^{\mathrm{GH}}$ & $44.82^{\mathrm{G}}$ & 44.84 & $45.06^{\mathrm{D}}$ & $41.64^{\mathrm{HI}}$ & 43.35 & $55.21^{\mathrm{GH}}$ & $32.62^{\mathrm{E}}$ & 43.92 & $48.25^{\mathrm{DE}}$ & $24.40^{\mathrm{DEF}}$ & 36.33 & 44.09 & 40.13 \\
\hline W2+E2 Sp & $44.16^{\mathrm{H}}$ & $43.71^{\mathrm{G}}$ & 43.94 & $39.18^{\mathrm{E}}$ & $35.48^{\mathrm{KL}}$ & 37.33 & $51.64^{\prime}$ & $27.79^{\mathrm{FGH}}$ & 39.72 & $44.58^{\mathrm{F}}$ & $22.74^{\mathrm{FGH}}$ & 33.66 & 40.64 & 36.69 \\
\hline & $29.04^{\mathrm{K}}$ & $31.78^{\mathrm{J}}$ & 30.41 & $22.29^{\mathrm{H}}$ & $28.55^{\mathrm{N}}$ & 25.42 & $41.35^{\mathrm{M}}$ & $20.05^{\llcorner}$ & 30.70 & 33.9 & $16.97^{\mathrm{J}}$ & 25.45 & 27.92 & 28.08 \\
\hline $\mathrm{W} 3+\mathrm{E}$ & $37.58^{1 \mathrm{~J}}$ & $39.61^{\mathrm{H}}$ & & 36.1 & & 37.0 & $45.98^{\mathrm{JK}}$ & $25.99^{\mathrm{HIJ}}$ & 35. & & $21.35^{\mathrm{GHI}}$ & & & 33.12 \\
\hline W3+E1 Sp & $34.85^{\lrcorner}$ & $38.54^{\mathrm{H}}$ & 36.69 & $35.50^{\mathrm{F}}$ & $34.15^{\mathrm{LM}}$ & 34.83 & $45.39^{\mathrm{KL}}$ & $24.59^{\mathrm{IJK}}$ & 34.99 & $36.94^{\mathrm{GH}}$ & $20.14^{\prime}$ & 28.54 & 35.76 & 31.77 \\
\hline W3+E2 Gs & $36.85^{\mathrm{IJ}}$ & $39.61^{\mathrm{H}}$ & 38.23 & 29.3 & $35.45^{\mathrm{KL}}$ & 32.40 & $45.26^{\mathrm{KL}}$ & $26.24^{\mathrm{HI}}$ & 35.75 & $38.44^{\mathrm{G}}$ & $21.08^{\mathrm{HI}}$ & 29.76 & 35.32 & 32.76 \\
\hline W3+E2 Sp & $30.84^{\mathrm{K}}$ & $36.27^{\prime}$ & 33.56 & $24.12^{\mathrm{H}}$ & $32.53^{\mathrm{M}}$ & 28.33 & $42.92^{\mathrm{LM}}$ & $23.67^{\mathrm{JK}}$ & 33.29 & $34.79^{\mathrm{HI}}$ & $19.30^{1}$ & 27.05 & 30.95 & 30.17 \\
\hline
\end{tabular}

E1 = Azotobacter chrocooccum E2 = Pseudomonas $s p$ Gs = Grains soaking Sp = foliar application control = 100 \% field capacity W1 = 75\% field capacity W2 $=50 \%$ field capacity $\quad$ W3 $=25 \%$ field capacity

Values within the same vertical areas with the same letter are not significantly different at $5 \%$ probability level by Duncan's Multiple Range Test 
Table 4 : Proline and relative water content (RWC) in the flag leaf of wheat cultivars Gmiza 9 and Sakha 93 as affected by different levels of water stress and two bacterial Endophytes and their interactions during 2009 / 2010 and 2010 / 2011 seasons.

\begin{tabular}{|c|c|c|c|c|c|c|c|c|c|c|c|c|}
\hline \multirow{3}{*}{ Treatment } & \multicolumn{4}{|c|}{ Gmiza 9} & \multicolumn{4}{|c|}{ Sakha 93} & \multirow{2}{*}{\multicolumn{2}{|c|}{ Means of }} & \multirow{2}{*}{\multicolumn{2}{|c|}{$\begin{array}{l}\text { Means of } \\
\text { RWC }\end{array}$}} \\
\hline & \multirow{2}{*}{$\begin{array}{c}2009 / \\
2010 \\
\text { Proline }\end{array}$} & \multirow{2}{*}{$\begin{array}{l}2010 / \\
2011 \\
\text { RWC }\end{array}$} & \multirow{2}{*}{$\begin{array}{c}2009 / \\
2010 \\
\text { Proline }\end{array}$} & \multirow{2}{*}{$\begin{array}{c}2010 / \\
2011 \\
\text { RWC }\end{array}$} & \multirow{2}{*}{$\begin{array}{c}2009 \text { / } \\
2010 \\
\text { Proline }\end{array}$} & \multirow{2}{*}{$\begin{array}{c}2010 / \\
2011 \\
\text { RWC }\end{array}$} & \multirow{2}{*}{\begin{tabular}{|c|}
$2009 /$ \\
2010 \\
Proline
\end{tabular}} & \multirow{2}{*}{$\begin{array}{c}2010 / \\
2011 \\
\text { RWC }\end{array}$} & & & & \\
\hline & & & & & & & & & $\begin{array}{c}\text { Gmiza } \\
9\end{array}$ & $\begin{array}{c}\text { Sakha } \\
93\end{array}$ & $\begin{array}{c}\text { Gmiza } \\
9\end{array}$ & $\begin{array}{c}\text { Sakha } \\
93\end{array}$ \\
\hline Control & $0.389^{J}$ & $80.98^{\mathrm{E}}$ & $0.418^{\mathrm{H}}$ & $87.10^{\mathrm{D}}$ & $0.440^{\mathrm{H}}$ & $98.27^{\mathrm{C}}$ & $0.585^{1}$ & $93.77^{\mathrm{C}}$ & 0.404 & 0.513 & 84.04 & 96.02 \\
\hline E 1 Gs & $0.397^{\lrcorner}$ & $88.53^{B}$ & $0.429^{H}$ & $95.07^{A}$ & $0.441^{\mathrm{H}}$ & $100.67^{B}$ & $0.576^{\prime}$ & $99.36^{A}$ & 0.413 & 0.509 & 91.80 & 100.02 \\
\hline E 1 Sp & $0.405^{J}$ & $85.04^{\mathrm{D}}$ & $0.420^{\mathrm{H}}$ & $90.05^{\mathrm{B}}$ & $0.412^{\mathrm{HI}}$ & $98.49^{\mathrm{C}}$ & $0.553^{\prime}$ & $96.10^{\mathrm{B}}$ & 0.413 & 0.483 & 87.55 & 97.29 \\
\hline E 2 Gs & $0.396^{J}$ & $89.89^{\mathrm{A}}$ & $0.417^{\mathrm{H}}$ & $93.92^{\mathrm{A}}$ & $0.435^{\mathrm{H}}$ & $103.18^{\mathrm{A}}$ & $0.580^{\prime}$ & $99.89^{\mathrm{A}}$ & 0.407 & 0.508 & 91.91 & 101.53 \\
\hline E 2 Sp & $0.406^{J}$ & $86.69^{C}$ & $0.418^{\mathrm{H}}$ & $91.25^{\mathrm{B}}$ & $0.389^{\prime}$ & $96.43^{\mathrm{D}}$ & $0.583^{\prime}$ & $94.09^{C}$ & 0.412 & 0.486 & 88.97 & 95.26 \\
\hline W 1 & $0.496^{1}$ & $76.16^{\mathrm{G}}$ & $0.557^{\mathrm{G}}$ & $71.26^{J}$ & $0.548^{\mathrm{G}}$ & $82.82^{\prime}$ & $0.724^{\mathrm{H}}$ & $77.95^{1}$ & 0.527 & 0.636 & 73.71 & 80.39 \\
\hline $\mathrm{W} 1+\mathrm{E} 1 \mathrm{Gs}$ & $0.613^{\mathrm{H}}$ & $85.44^{\mathrm{D}}$ & $0.722^{F}$ & $86.32^{\mathrm{D}}$ & $0.650^{\mathrm{F}}$ & $96.12^{\mathrm{D}}$ & $0.957^{F}$ & $89.73^{\mathrm{D}}$ & 0.668 & 0.804 & 85.88 & 92.93 \\
\hline $\mathrm{W} 1+\mathrm{E} 1 \mathrm{Sp}$ & $0.606^{\mathrm{H}}$ & $80.75^{\mathrm{E}}$ & $0.697^{F}$ & $84.58^{\mathrm{E}}$ & $0.619^{F}$ & $94.21^{\mathrm{E}}$ & $0.946^{F G}$ & $86.85^{\mathrm{E}}$ & 0.652 & 0.783 & 82.67 & 90.53 \\
\hline W $1+E 2$ Gs & $0.625^{\mathrm{H}}$ & $86.71^{\mathrm{C}}$ & $0.713^{F}$ & $88.53^{\mathrm{C}}$ & $0.639^{F}$ & $96.65^{\mathrm{D}}$ & $0.951^{\mathrm{F}}$ & $89.41^{\mathrm{D}}$ & 0.669 & 0.795 & 87.62 & 93.03 \\
\hline $\mathrm{W} 1+\mathrm{E} 2 \mathrm{Sp}$ & $0.612^{\mathrm{H}}$ & $81.34^{\mathrm{E}}$ & $0.697^{F}$ & $82.70^{\mathrm{F}}$ & $0.634^{F}$ & $92.73^{\mathrm{EF}}$ & $0.906^{\mathrm{G}}$ & $84.68^{\mathrm{F}}$ & 0.655 & 0.770 & 82.02 & 88.71 \\
\hline W 2 & $0.753^{\mathrm{G}}$ & $64.51^{\mathrm{J}}$ & $0.872^{\mathrm{E}}$ & $61.24^{\mathrm{L}}$ & $0.844^{\mathrm{E}}$ & $73.81^{\mathrm{L}}$ & $1.026^{\mathrm{E}}$ & 65. & 0.813 & 0.935 & 62.88 & 69.62 \\
\hline $\mathrm{W}_{2}+\mathrm{E}_{1} \mathrm{Gs}$ & $0.856^{\mathrm{EF}}$ & $80.35^{\mathrm{E}}$ & $1.047^{\mathrm{CD}}$ & $77.97^{\mathrm{G}}$ & $0.995^{\mathrm{D}}$ & $93.02^{\mathrm{EF}}$ & $1.221^{\mathrm{D}}$ & $87.16^{\mathrm{E}}$ & 0.952 & 1.108 & 79.16 & 90.09 \\
\hline W 2 + E1 Sp & $0.834^{F}$ & $78.38^{F}$ & $1.003^{\mathrm{D}}$ & $73.28^{1}$ & $0.966^{\mathrm{D}}$ & $89.32^{\mathrm{G}}$ & $1.213^{\mathrm{D}}$ & $83.31^{G}$ & 0.919 & 1.089 & 75.83 & 86.32 \\
\hline $\mathrm{W} 2+\mathrm{E} 2 \mathrm{Gs}$ & $0.865^{\mathrm{E}}$ & $80.27^{\mathrm{E}}$ & $1.035^{\mathrm{CD}}$ & $78.86^{G}$ & $0.986^{\mathrm{D}}$ & $91.72^{\mathrm{F}}$ & $1.253^{\mathrm{D}}$ & $86.19^{\mathrm{E}}$ & 0.950 & 1.119 & 79.57 & 88.96 \\
\hline $\mathrm{W} 2+\mathrm{E} 2 \mathrm{Sp}$ & $0.843^{\mathrm{EF}}$ & $78.82^{F}$ & $1.002^{\mathrm{D}}$ & $75.54^{\mathrm{H}}$ & $0.986^{\mathrm{D}}$ & $89.76^{\mathrm{G}}$ & $1.211^{\mathrm{D}}$ & $80.09^{\mathrm{H}}$ & 0.923 & 1.098 & 77.18 & 84.93 \\
\hline W 3 & $0.952^{\mathrm{D}}$ & $49.31^{\mathrm{K}}$ & $1.079^{\mathrm{C}}$ & $47.14^{\mathrm{M}}$ & $1.070^{\mathrm{C}}$ & $51.96^{\mathrm{M}}$ & $1.327^{\mathrm{C}}$ & $49.58^{\mathrm{M}}$ & 1.016 & 1.199 & 48.23 & 50.77 \\
\hline E 1 Gs & $1.233^{\mathrm{B}}$ & $74.57^{\mathrm{H}}$ & $1.415^{\mathrm{A}}$ & $73.18^{\prime}$ & $1.436^{\mathrm{A}}$ & $84.68^{\mathrm{H}}$ & $1.567^{\mathrm{A}}$ & $78.63^{1}$ & 1.324 & 3.002 & 73.88 & 81.66 \\
\hline W $3+E 1 S p$ & $1.215^{\mathrm{BC}}$ & $71.23^{\prime}$ & $1.363^{\mathrm{B}}$ & $70.08^{\mathrm{JK}}$ & $1.347^{\mathrm{B}}$ & $79.78^{J}$ & $1.548^{\mathrm{AB}}$ & $74.74^{\mathrm{J}}$ & 1.289 & 1.448 & 70.66 & 77.26 \\
\hline W $3+E 2 G s$ & $1.264^{\mathrm{A}}$ & $75.35^{\mathrm{GH}}$ & $1.411^{\mathrm{A}}$ & $70.82^{\mathrm{J}}$ & $1.420^{\mathrm{A}}$ & $83.12^{1}$ & $1.513^{\mathrm{B}}$ & $75.93^{\mathrm{J}}$ & 1.338 & 1.467 & 73.09 & 79.53 \\
\hline W 3 + E 2 Sp & $1.203^{\mathrm{C}}$ & $72.19^{1}$ & $1.414^{\mathrm{A}}$ & $68.90^{\mathrm{K}}$ & $1.363^{\mathrm{B}}$ & $77.24^{\mathrm{K}}$ & $1.518^{\mathrm{B}}$ & $73.11^{\mathrm{K}}$ & 1.309 & 1.441 & 70.55 & 75.18 \\
\hline
\end{tabular}

E1 = Azotobacter chrocooccum E2 = Pseudomonas sp Gs = Grains soaking Sp = foliar application control = 100\% field capacity W1 = $75 \%$ field capacity W2 $=50 \%$ field capacity $\quad$ W3 $=25 \%$ field capacity Values within the same vertical areas with the same letter are not significantly different at $5 \%$ probability level by Duncan's Multiple Range
Test 
J. Plant Production, Mansoura Univ., Vol. 3 (7), July, 2012

Table 5: Leaf water content (LWC) and leaf water deficit (LWD) in the flag leaf of wheat cultivars Gmiza 9 and Sakha 93 as affected by different levels of water stress and different Endophytes bacteria and their interactions during 2009 / 2010 and 2010 / 2011 seasons.

\begin{tabular}{|c|c|c|c|c|c|c|c|c|c|c|c|c|}
\hline \multirow{3}{*}{ Treatment } & \multicolumn{4}{|c|}{ Gmiza 9} & \multicolumn{4}{|c|}{ Sakha 93} & \multirow{2}{*}{\multicolumn{2}{|c|}{ Gmiza 9 mean }} & \multirow{2}{*}{\multicolumn{2}{|c|}{ Sakha 93 mean }} \\
\hline & \multirow{2}{*}{$\begin{array}{c}2009 / \\
2010 \\
\text { LWC }\end{array}$} & \multirow{2}{*}{$\begin{array}{c}2010 / \\
2011 \\
\text { LWC }\end{array}$} & \multirow{2}{*}{$\begin{array}{l}2009 / \\
2010 \\
\text { LWD }\end{array}$} & \multirow{2}{*}{$\begin{array}{c}2010 / \\
2011 \\
\text { LWD }\end{array}$} & \multirow{2}{*}{$\begin{array}{c}2009 / \\
2010 \\
\text { LWD }\end{array}$} & \multirow{2}{*}{$\begin{array}{c}2010 / \\
2011 \\
\text { LWD }\end{array}$} & \multirow{2}{*}{$\begin{array}{c}2009 / \\
2010 \\
\text { LWC }\end{array}$} & \multirow{2}{*}{$\begin{array}{c}2010 / \\
2011 \\
\text { LWC }\end{array}$} & & & & \\
\hline & & & & & & & & & LWC & LWD & LWC & LWD \\
\hline Control & $2.92 \mathrm{~F}$ & $3.15 \mathrm{FG}$ & $19.02 \mathrm{G}$ & 12.90JK & $1.37 \mathrm{~K}$ & $6.23 \mathrm{~K}$ & $2.54 \mathrm{FG}$ & $2.83 G$ & 3.04 & 15.96 & 2.69 & 3.80 \\
\hline & $3.65 \mathrm{~A}$ & $3.82 \mathrm{~A}$ & 11.471 & $4.93 \mathrm{~N}$ & 00.00 & $0.69 \mathrm{M}$ & $2.98 \mathrm{~A}$ & $3.26 \mathrm{~A}$ & 3.74 & 8.20 & 3.12 & 0.35 \\
\hline E 1Sp & $3.21 C D$ & $3.61 \mathrm{C}$ & $14.96 \mathrm{H}$ & 9.95LM & $1.51 \mathrm{~K}$ & $3.90 \mathrm{~L}$ & $2.70 \mathrm{D}$ & $3.13 \mathrm{C}$ & 3.41 & 12.46 & 2.92 & 2.71 \\
\hline E 2 Sp & $3.46 \mathrm{~B}$ & $3.69 \mathrm{~B}$ & 10.111 & $6.08 \mathrm{~N}$ & 00.00 & $0.14 \mathrm{M}$ & $2.85 \mathrm{~B}$ & $3.20 \mathrm{~B}$ & 3.58 & 8.09 & 3.03 & 0.07 \\
\hline & $3.29 \mathrm{C}$ & 3.43D & $13.31 \mathrm{H}$ & $8.75 \mathrm{M}$ & 3.57J & $5.91 \mathrm{~K}$ & $2.61 \mathrm{E}$ & 3.07D & 3.36 & 11.03 & 2.84 & 4.74 \\
\hline $\mid \begin{array}{l}W 1 \\
W 1+E 1 G s\end{array}$ & $2.14 \mathrm{~J}$ & $2.61 \mathrm{~L}$ & $23.84 \mathrm{D}$ & 29.07D & $17.18 \mathrm{E}$ & $22.05 \mathrm{E}$ & $2.19 \mathrm{~J}$ & 1.690 & 2.38 & 26.46 & 1.94 & 19.62 \\
\hline W $1+E 1$ & $3.47 \mathrm{~B}$ & $3.40 \mathrm{D}$ & $14.56 \mathrm{H}$ & $13.68 \mathrm{~J}$ & $3.88 \mathrm{~J}$ & $10.27 \mathrm{~J}$ & $2.78 \mathrm{C}$ & $2.94 \mathrm{~F}$ & 3.44 & 14.12 & 2.86 & 7.08 \\
\hline & 3.15DE & $3.24 \mathrm{E}$ & $19.25 G$ & 15.421 & 5.791 & 13.151 & $2.59 \mathrm{E}$ & $2.74 \mathrm{H}$ & 3.19 & 17.34 & 2.67 & 9.47 \\
\hline W1 $1+E 2$ Gs & $3.41 \mathrm{~B}$ & $3.37 \mathrm{D}$ & $13.29 \mathrm{H}$ & $11.47 \mathrm{KL}$ & $3.35 \mathrm{~J}$ & $10.59 \mathrm{~J}$ & $2.73 \mathrm{CD}$ & $3.02 \mathrm{E}$ & 3.39 & 12.38 & 2.88 & 6.97 \\
\hline & 3.08E & $3.06 \mathrm{H}$ & $18.66 \mathrm{G}$ & $17.30 \mathrm{H}$ & $7.27 \mathrm{HI}$ & $15.32 \mathrm{H}$ & $2.53 G$ & $2.79 \mathrm{G}$ & 3.07 & 17.98 & 2.66 & 11.29 \\
\hline W 2 & $1.99 \mathrm{~K}$ & 2.110 & $35.49 \mathrm{~B}$ & $38.76 \mathrm{~B}$ & $26.19 \mathrm{~B}$ & $34.58 \mathrm{~B}$ & $1.99 \mathrm{~L}$ & $1.45 \mathrm{P}$ & 2.05 & 37.13 & 1.72 & 30.39 \\
\hline W 2 + E1 Gs & $2.97 \mathrm{~F}$ & 3.19EF & $19.65 \mathrm{FG}$ & $22.03 \mathrm{G}$ & $6.98 \mathrm{HI}$ & $12.84 \mid$ & $2.59 \mathrm{EF}$ & $2.64 \mid$ & 3.08 & 20.84 & 2.62 & 9.91 \\
\hline W 2 + E1 Sp & $2.79 \mathrm{G}$ & $3.08 \mathrm{GH}$ & $21.62 \mathrm{E}$ & $26.72 \mathrm{E}$ & $10.68 \mathrm{G}$ & $16.69 \mathrm{G}$ & $2.43 \mathrm{H}$ & $2.38 \mathrm{~K}$ & 2.94 & 24.17 & 2.41 & 13.69 \\
\hline W $2+E 2$ Gs & $2.98 \mathrm{~F}$ & $3.04 \mathrm{H}$ & $19.73 \mathrm{FG}$ & $21.14 G$ & $8.28 \mathrm{H}$ & 13.811 & $2.61 \mathrm{E}$ & $2.53 \mathrm{~J}$ & 3.01 & 20.44 & 2.57 & 11.05 \\
\hline $\mid \begin{array}{l}\mathrm{W} 22+\mathrm{E} 2 \\
\mathrm{Sp}\end{array}$ & $2.75 \mathrm{G}$ & $2.85 \mathrm{~J}$ & 21.18EF & $24.46 \mathrm{~F}$ & $10.24 \mathrm{G}$ & $19.91 \mathrm{~F}$ & $2.46 \mathrm{H}$ & $2.28 \mathrm{~L}$ & 2.80 & 22.82 & 2.37 & 15.08 \\
\hline w 3 & $1.52 \mathrm{~L}$ & $1.79 \mathrm{P}$ & $50.69 \mathrm{~A}$ & $52.86 \mathrm{~A}$ & $48.04 \mathrm{~A}$ & $50.42 \mathrm{~A}$ & $1.49 \mathrm{M}$ & $1.12 \mathrm{Q}$ & 1.66 & 51.78 & 1.31 & 49.23 \\
\hline W $3+$ & $2.70 \mathrm{GH}$ & $2.77 \mathrm{~K}$ & $25.43 \mathrm{D}$ & $26.82 \mathrm{E}$ & $15.32 \mathrm{~F}$ & $21.37 \mathrm{E}$ & 2.381 & $2.28 \mathrm{~L}$ & 2.74 & 26.13 & 2.33 & 18.35 \\
\hline $\mathrm{W} 3+\mathrm{E} 1 \mathrm{Sp}$ & 2.501 & $2.44 \mathrm{M}$ & $28.77 \mathrm{C}$ & $29.92 \mathrm{CD}$ & $20.22 \mathrm{D}$ & $25.26 \mathrm{D}$ & $2.15 \mathrm{JK}$ & $2.12 \mathrm{~N}$ & 2.47 & 29.35 & 2.14 & 22.74 \\
\hline W 3 + E2 Gs & $2.65 \mathrm{H}$ & 2.951 & $24.65 \mathrm{D}$ & $29.18 D$ & $16.88 \mathrm{E}$ & $24.07 \mathrm{D}$ & 2.351 & $2.36 \mathrm{~K}$ & 2.80 & 26.92 & 2.36 & 20.48 \\
\hline W 3 & 2.511 & $2.24 \mathrm{~N}$ & $27.81 \mathrm{C}$ & $31.10 \mathrm{C}$ & $22.76 \mathrm{C}$ & $26.89 \mathrm{C}$ & $2.13 \mathrm{~K}$ & $2.18 \mathrm{M}$ & 2.38 & 29.46 & 1.09 & 24.83 \\
\hline
\end{tabular}

1 = Azotobacter chrocooccum E2 = Pseudomonas sp Gs = Grains soaking Sp = foliar application control = 100 \% field capacity W1 = 75\% field capacity W2 $=50 \%$ field capacity $\quad W 3=25 \%$ field capacity

Values within the same vertical areas with the same letter are not significantly different at $5 \%$ probability level by Duncan's Multiple Range Test 
Table 6: Nitrogen $\%$ and crude protein in the flag leaf of wheat cultivars Gmiza 9 and Sakha 93 wheat plants as affected by different levels of water stress and two different bacterial endophytes and their interactions during 2009 / 2010 and 2010 / 2011 seasons.

\begin{tabular}{|c|c|c|c|c|c|c|c|c|}
\hline \multirow{3}{*}{ Treatment } & \multicolumn{4}{|c|}{ Gmiza 9} & \multicolumn{4}{|c|}{ Sakha 93} \\
\hline & \multicolumn{2}{|c|}{$2009 / 2010$} & \multicolumn{2}{|c|}{2010 / 2011} & \multicolumn{2}{|c|}{$2009 / 2010$} & \multicolumn{2}{|c|}{$2010 / 2011$} \\
\hline & $\mathrm{N} \%$ & Crude Protein & $\mathrm{N} \%$ & \begin{tabular}{|l|} 
Crude Protein \\
\end{tabular} & $\mathbf{N} \%$ & Crude Protein & $\mathrm{N} \%$ & Crude Protein \\
\hline Control & $2.67^{\mathrm{C}}$ & $16.69^{\mathrm{C}}$ & $2.33^{\mathrm{C}}$ & $14.58^{\mathrm{C}}$ & $1.84^{\mathrm{D}}$ & $11.52^{\mathrm{D}}$ & $2.21^{\mathrm{CD}}$ & $13.78^{\mathrm{CD}}$ \\
\hline E 1 Gs & $3.19^{A}$ & $19.98^{\mathrm{A}}$ & $3.06^{A}$ & $19.10^{A}$ & $2.49^{A}$ & $15.60^{A}$ & $2.98^{\mathrm{A}}$ & $18.59^{\mathrm{A}}$ \\
\hline E $1 \mathrm{Sp}$ & $2.99^{\mathrm{B}}$ & $18.67^{B}$ & $2.79^{\mathrm{B}}$ & $17.43^{B}$ & $2.11^{\mathrm{C}}$ & $13.19^{C}$ & $2.72^{\mathrm{B}}$ & $16.99^{B}$ \\
\hline E 2 Gs & $3.14^{\mathrm{A}}$ & $19.61^{\mathrm{A}}$ & $2.99^{\mathrm{A}}$ & $18.67^{A}$ & $2.29^{\mathrm{B}}$ & $14.36^{\mathrm{B}}$ & $3.03^{\mathrm{A}}$ & $18.96^{\mathrm{A}}$ \\
\hline E 2 Sp & $3.02^{\mathrm{B}}$ & $18.89^{\mathrm{B}}$ & $2.79^{\mathrm{B}}$ & $17.43^{\mathrm{B}}$ & $2.14^{\mathrm{C}}$ & $13.34^{\mathrm{C}}$ & $2.67^{\mathrm{B}}$ & $16.698^{\mathrm{B}}$ \\
\hline W 1 & $2.32^{\mathrm{E}}$ & $14.51^{\mathrm{E}}$ & $2.10^{\mathrm{E}}$ & $13.13^{\mathrm{E}}$ & $1.66^{\mathrm{EF}}$ & $10.35^{\mathrm{EF}}$ & $1.83^{\mathrm{G}}$ & $11.45^{\mathrm{G}}$ \\
\hline $\mathrm{W} 1+\mathrm{E} 1 \mathrm{Gs}$ & $2.63^{\mathrm{C}}$ & $16.41^{\mathrm{C}}$ & $2.32^{\mathrm{C}}$ & $14.51^{\mathrm{C}}$ & $1.86^{\mathrm{D}}$ & $11.59^{\mathrm{D}}$ & $2.22^{\mathrm{CD}}$ & $13.85^{\mathrm{CD}}$ \\
\hline $\mathrm{W} 1+\mathrm{E} 1 \mathrm{Sp}$ & $2.64^{\mathrm{C}}$ & $16.48^{\mathrm{C}}$ & $2.26^{\mathrm{CD}}$ & $14.15^{\mathrm{CD}}$ & $1.79^{\mathrm{D}}$ & $11.16^{\mathrm{D}}$ & $2.14^{\mathrm{DE}}$ & $13.34^{\mathrm{DE}}$ \\
\hline $\mathrm{W} 1+\mathrm{E} 2 \mathrm{Gs}$ & $2.49^{\mathrm{D}}$ & $15.53^{\mathrm{D}}$ & $2.33^{\mathrm{C}}$ & $14.58^{\mathrm{C}}$ & $1.83^{\mathrm{D}}$ & $11.45^{\mathrm{D}}$ & $2.28^{\mathrm{C}}$ & $14.22^{\mathrm{C}}$ \\
\hline W 1 + E 2 Sp & $2.65^{\mathrm{C}}$ & $16.55^{\mathrm{C}}$ & $2.19^{\mathrm{D}}$ & $13.71^{\mathrm{D}}$ & $1.75^{\mathrm{DE}}$ & $10.94^{\mathrm{DE}}$ & $2.08^{\mathrm{EF}}$ & $12.97^{\mathrm{EF}}$ \\
\hline W 2 & $1.77^{\mathrm{H}}$ & $11.08^{\mathrm{H}}$ & $1.84^{\mathrm{HI}}$ & $11.52^{\mathrm{HI}}$ & $1.33^{\mathrm{H}}$ & $8.31^{\mathrm{H}}$ & $1.53^{\mathrm{H}}$ & $9.55^{\mathrm{H}}$ \\
\hline W 2 + E1 Gs & $2.17^{\mathrm{F}}$ & $13.56^{\mathrm{F}}$ & $2.10^{\mathrm{E}}$ & $13.13^{\mathrm{E}}$ & $1.65^{\mathrm{EF}}$ & $10.28^{\mathrm{EF}}$ & $1.98^{\mathrm{F}}$ & $12.39^{\mathrm{F}}$ \\
\hline $\mathrm{W} 2+\mathrm{E} 1 \mathrm{Sp}$ & $2.17^{\mathrm{F}}$ & $13.56^{\mathrm{F}}$ & $2.05^{\mathrm{E}}$ & $12.83^{\mathrm{E}}$ & $1.56^{\mathrm{FG}}$ & $9.77^{\mathrm{FG}}$ & $1.76^{\mathrm{G}}$ & $11.01^{\mathrm{G}}$ \\
\hline $\mathrm{W} 2+\mathrm{E} 2 \mathrm{Gs}$ & $2.10^{\mathrm{F}}$ & $13.13^{\mathrm{F}}$ & $1.97^{\mathrm{F}}$ & $12.32^{\mathrm{F}}$ & $1.63^{\mathrm{EF}}$ & $10.21^{\mathrm{EF}}$ & $1.98^{\mathrm{F}}$ & $12.39^{\mathrm{F}}$ \\
\hline W $2+E 2 S p$ & $2.15^{\mathrm{F}}$ & $13.42^{\mathrm{F}}$ & $1.97^{\mathrm{F}}$ & $12.32^{\mathrm{F}}$ & $1.48^{\mathrm{G}}$ & $9.26^{\mathrm{G}}$ & $1.74^{\mathrm{G}}$ & $10.86^{G}$ \\
\hline W 3 & $1.45^{\mathrm{J}}$ & $9.04^{J}$ & $1.59^{\mathrm{J}}$ & $9.99^{\mathrm{J}}$ & $0.83^{\mathrm{K}}$ & $5.17^{\mathrm{K}}$ & $1.06^{\mathrm{J}}$ & $6.64^{\mathrm{J}}$ \\
\hline W 3 +E 1 Gs & $1.99^{G}$ & $12.47^{\mathrm{G}}$ & $1.93^{\mathrm{FG}}$ & $12.03^{\mathrm{FG}}$ & $1.26^{\mathrm{HI}}$ & $7.88^{\mathrm{HI}}$ & $1.44^{\mathrm{HI}}$ & $8.97^{\mathrm{HI}}$ \\
\hline W 3 + E 1 Sp & $1.94^{\mathrm{G}}$ & $12.10^{\mathrm{G}}$ & $1.79^{1}$ & $11.16^{1}$ & $1.18^{\mathrm{IJ}}$ & $7.36^{1 \mathrm{~J}}$ & $1.40^{\prime}$ & $8.75^{1}$ \\
\hline $\mathrm{W} 3+\mathrm{E} 2 \mathrm{Gs}$ & $1.67^{1}$ & $10.43^{\prime}$ & $1.91^{\mathrm{FGH}}$ & $11.96^{\mathrm{FGH}}$ & $1.23^{\mathrm{HIJ}}$ & $7.66^{\mathrm{HIJ}}$ & $1.48^{\mathrm{HI}}$ & $9.26^{\mathrm{HI}}$ \\
\hline W $3+E 2$ Sp & $1.79^{\mathrm{H}}$ & $11.16^{\mathrm{H}}$ & $1.87^{\mathrm{GH}}$ & $11.67^{\mathrm{GH}}$ & $1.12^{\mathrm{J}}$ & $7.00^{\mathrm{J}}$ & $1.39^{1}$ & $8.68^{\prime}$ \\
\hline
\end{tabular}

E1 = Azotobacter chrocooccum E2 = Pseudomonas sp Gs = Grains soaking Sp = foliar application control = 100 \% field capacity W1 = 75\% field capacity W2 $=50 \%$ field capacity $\quad W 3=25 \%$ field capacity

Values within the same vertical areas with the same letter are not significantly different at $5 \%$ probability level by Duncan's Multiple Range Test 